\title{
Multi-decadal records of stratospheric composition and their relationship to stratospheric circulation change
}

\author{
Anne R. Douglass ${ }^{1}$, Susan E. Strahan ${ }^{1,2}$, Luke D. Oman ${ }^{1}$, and Richard S. Stolarski ${ }^{3}$ \\ ${ }^{1}$ Atmospheric Chemistry and Dynamics Laboratory, NASA Goddard Space Flight Center, Greenbelt, MD, USA \\ ${ }^{2}$ Universities Space Research Association, Columbia, MD, USA \\ ${ }^{3}$ Department of Earth and Planetary Sciences, Johns Hopkins University, Baltimore, MD, USA
}

Correspondence to: Anne R. Douglass (anne.r.douglass@nasa.gov)

Received: 30 April 2017 - Discussion started: 1 June 2017

Revised: 30 August 2017 - Accepted: 4 September 2017 - Published: 12 October 2017

\begin{abstract}
Constituent evolution for 1990-2015 simulated using the Global Modeling Initiative chemistry and transport model driven by meteorological fields from the Modern-Era Retrospective analysis for Research and Applications version 2 (MERRA-2) is compared with three sources of observations: ground-based column measurements of $\mathrm{HNO}_{3}$ and $\mathrm{HCl}$ from two stations in the Network for the Detection of Atmospheric Composition Change (NDACC, 1990ongoing), profiles of $\mathrm{CH}_{4}$ from the Halogen Occultation Experiment (HALOE) on the Upper Atmosphere Research Satellite (UARS, 1992-2005), and profiles of $\mathrm{N}_{2} \mathrm{O}$ from the Microwave Limb Sounder on the Earth Observing System satellite Aura (2005-ongoing). The differences between observed and simulated values are shown to be time dependent, with better agreement after $\sim 2000$ compared with the prior decade. Furthermore, the differences between observed and simulated $\mathrm{HNO}_{3}$ and $\mathrm{HCl}$ columns are shown to be correlated with each other, suggesting that issues with the simulated transport and mixing cause the differences during the 1990s and that these issues are less important during the later years. Because the simulated fields are related to mean age in the lower stratosphere, we use these comparisons to evaluate the time dependence of mean age. The ongoing NDACC column observations provide critical information necessary to substantiate trends in mean age obtained using fields from MERRA-2 or any other reanalysis products.
\end{abstract}

\section{Introduction}

The composition of the stratosphere is changing in response to changes in ozone-depleting substances (ODSs), nitrous oxide $\left(\mathrm{N}_{2} \mathrm{O}\right)$ and methane $\left(\mathrm{CH}_{4}\right)$ with consequences for the ozone layer, stratospheric circulation, stratosphere-troposphere exchange and climate. ODSs (primarily chlorine- and bromine-containing compounds) are decreasing due to cessation of their production as a result of the Montreal Protocol and its amendments. These man-made compounds are greenhouse gases (Ramanathan, 1975). $\mathrm{N}_{2} \mathrm{O}$ and $\mathrm{CH}_{4}$ are sources of nitrogen and hydrogen radicals, and are also greenhouse gases. The concentrations of $\mathrm{N}_{2} \mathrm{O}$ and $\mathrm{CH}_{4}$ are presently increasing, as discussed by Carpenter et al. (2014) for recent decades, and reflected in boundary conditions that are prescribed for the simulations (Sect. 3). The stratospheric climate is changing in response to composition change, as increased greenhouse gases both cool the stratosphere and accelerate the stratospheric circulation (Butchart and Scaife, 2001). Both decreases in ODSs and cooling due to the increase in greenhouse gases cause ozone to increase by reducing ozone loss. Acceleration of the circulation causes column ozone to decrease in the tropics and increase at middle and high latitudes (Li et al., 2009). The net ozone layer response is a combination of photochemical and dynamical changes, as well as feedbacks in ozone heating and photochemistry that link them.

Future evolution of the ozone layer is commonly investigated using three-dimensional chemistry-climate models (CCMs) that combine a general circulation model (GCM) with a representation of photochemical and radiative processes. A common feature of middle-atmosphere GCMs 
(without interactive chemistry) and CCMs (with interactive chemistry) is the intensification of the Brewer-Dobson circulation (BDC) in the 21st century due to increases in greenhouse gases (Butchart et al., 2006). BDC strengthening could manifest itself in many ways that impact ozone. Some observations in the tropics support BDC acceleration during the past few decades, but overall attempts to verify this prediction of models with measurements has resulted in mixed conclusions, as exemplified in the following paragraphs.

Kawatani and Hamilton (2013) find that tropical radiosonde observations for 1953-2012 show weakening of the quasi-biennial oscillation (QBO) that is consistent with increased tropical upwelling. Thompson and Solomon (2009) argue that for 1979-2006, microwave sounding unit channel 4 temperature retrievals and the merged total ozone data set (McPeters et al., 2013; Frith et al., 2014) are consistent with BDC acceleration after accounting for the effects of volcanic eruptions. Integrated ozone profiles from the Stratospheric Aerosol and Gas Experiment (SAGE I and SAGE II) show ozone decreases of about 10 DU (Dobson units) between 1979 and 2005 (Randel and Wu, 2007), consistent with decreases in tropical lower-stratospheric ozone from a record for 1984-2009 obtained by combining SAGE II data with SHADOZ ozonesondes (Randel and Thompson, 2011), but inconsistent with the nearly constant time series of tropical total column ozone (Pawson and Steinbrecht, 2015). Tropical lower-stratospheric ozone increases measured by the Scanning Imaging Absorption Spectrometer for Atmospheric CHartographY (SCIAMACHY), an instrument on Envisat (2002-2012), are also not consistent with a predicted circulation increase (Gebhardt et al., 2014). Harris et al. (2015) report no statistically significant $\mathrm{O}_{3}$ trend in the tropical lower stratosphere. Simulations reported by Shepherd et al. (2014) produce an increase in tropospheric ozone that compensates for the stratospheric decrease, potentially resolving the discrepancy between the total column ozone record and the records that combine SAGE II with SAGE I or SHADOZ. Polvani et al. (2017) find that the ODSs themselves are primary drivers of tropical upwelling, in which case the decrease in ODSs over the coming decades will counter or reverse the impact of other greenhouse gases on the circulation. The future evolution of tropical column ozone is complex and may be influenced by circulation change, changes in tropospheric pollution or both.

In the extratropics, intensification of the BDC will alter the distributions of source gases, including anthropogenic chlorofluorocarbons (Butchart and Scaife, 2001), increase the midlatitude stratosphere-to-troposphere ozone flux (Hegglin and Shepherd, 2009) and decrease the stratospheric mean age (Li and Waugh, 1999; Austin and Li, 2006). Although all CCMs predict increased tropical upwelling in the 21 st century, both the rate of tropical increase and the response of the extratropical circulation differ substantially. Douglass et al. (2014) show that differences in the details of the intensification of the extratropical circulation make major contribu- tions to the spread in the stratospheric ozone level projected for 2100 obtained from the CCMs that contributed to a comprehensive effort to evaluate these models (SPARC CCMVal, 2010) and the Scientific Assessment of Ozone Depletion: 2010 (WMO, 2011).

There have been efforts to quantify BDC trends and variability as expressed in meteorological analyses. Diallo et al. (2012) report statistically significant negative age trends in the extratropics using meteorological fields from ERAInterim for 1989-2010. Abalos et al. (2015) find common features that support negative age trends in the advective Brewer-Dobson circulation for 1979-2012 in ERA-Interim, the Modern-Era Retrospective analysis for Research and Applications (MERRA) and the Japanese 55-year Reanalysis for 1979-2012. Ploeger et al. (2015) use the Chemical Lagrangian Model of the Stratosphere (CLaMS), driven by ERA-Interim reanalysis, to show how changes in both mixing and the residual circulation contribute to trends in age of air. Any of these results would be affected by changes in the observing system, and Diallo et al. (2012) caution that such changes may lead to false trends in the age obtained from analyzed fields. They emphasize the need for comparisons with trends derived from tracer observations. Furthermore, deficiencies in the GCM component of a reanalysis system such as lack of a spontaneous QBO may lead to spurious tropical ascent and subtropical mixing, also contributing to false trends (Tan et al., 2004; Coy et al., 2016).

Long-lived constituents (e.g., $\mathrm{CFCl}_{3}, \mathrm{CF}_{2} \mathrm{Cl}_{2}, \mathrm{~N}_{2} \mathrm{O}$ ), reservoir species that are products of their destruction (e.g., $\mathrm{HNO}_{3}$ and $\mathrm{HCl}$ ), and age tracers like $\mathrm{SF}_{6}$ and $\mathrm{CO}_{2}$ all carry information about changes in the circulation and mixing (Hall, 2000). Engel et al. (2009) find no statistically significant trend in the northern midlatitude mean age derived from sparse balloon profiles of $\mathrm{SF}_{6}$ and $\mathrm{CO}_{2}$ between 1985 and 2005. Ray et al. (2010) used the same observations and trends in the tropical vertical velocity obtained from reanalysis data sets to show how trends in both horizontal mixing and upwelling affect the midlatitude age trends, and they find that the age changes indicated by the measurements differ from those produced by the CCMVal models. Garcia et al. (2011) show the importance of accounting for nonlinear growth rates of the age tracers when comparing simulated ages with those derived from balloon observations. Ray et al. (2014) identify seasonal, quasi-biennial and decadal scales of variability in the middle latitude mean age by extending their previous analysis, accounting for variable growth rates in $\mathrm{SF}_{6}$ and $\mathrm{CO}_{2}$ and adjusting the measurementbased mean ages to a common equivalent latitude that is representative of the Northern Hemisphere (NH).

Prior use of source gases to infer variability in mean age is limited. Schoeberl et al. (2005) explored the relationship between mean age and trace gas distributions in a chemistry transport model (CTM) driven by winds from a GCM, interpreting their results using observations of $\mathrm{CH}_{4}, \mathrm{~N}_{2} \mathrm{O}$, and chlorofluorocarbons $\mathrm{CF}_{2} \mathrm{Cl}_{2}$ and $\mathrm{CFCl}_{3}$ from the cryogenic 
limb array etalon spectrometer (CLAES) on NASA's Upper Atmosphere Research Satellite (Roche et al., 1996) and from the Atmospheric Chemistry Experiment Fourier transform spectrometer (ACE-FTS) on the Canadian SCISAT (Bernath et al., 2005). They associate young mean ages with high values of tracers seen by CLAES at the northern lower middle latitudes in 1993 and older mean ages with lower values for ACE-FTS tracers in 2005, speculating that the different relationships during these two periods are evidence of quasibiennial variability in the mean age. Strahan et al. (2015) showed the signature of the QBO in the variability of the southern midlatitude middle stratosphere $\mathrm{N}_{2} \mathrm{O}$ and mean age using 9 years of observations from the Microwave Limb Sounder (MLS) on NASA's Earth Observing System (EOS) Aura.

A recent analysis of $\mathrm{HCl}$ column measurements from stations in the Network for the Detection of Atmospheric Composition Change (NDACC) highlights the relationship between mean age, low-frequency variability and the $\mathrm{HCl}$ column amounts. Both satellite and ground-based observations show an increase in $\mathrm{NH}$ column and lower-stratospheric $\mathrm{HCl}$ between 2007 and 2011 (Mahieu et al., 2014). CTM simulations using meteorological fields from ERA-Interim reproduce the lower-stratospheric pattern of $\mathrm{NH} \mathrm{HCl}$ increase and Southern Hemisphere ( $\mathrm{SH}$ ) decrease, consistent with an increase in the mean age and a slowdown in the $\mathrm{NH}$ midlatitude lower-stratospheric circulation. The $\mathrm{HCl}$ increase indicates air with older mean age that has spent more time at higher altitudes (Hall, 2000), where it experiences rapid chlorofluorocarbon destruction leading to higher levels of $\mathrm{HCl}$. The magnitude and duration of the $\mathrm{HCl}$ column increase attests to the importance of quantifying the natural variability that produced it. Large natural multi-annual variations make it more difficult to quantify trends in the circulation, to identify a decrease in inorganic chlorine caused by the decrease in ODSs or to attribute an ozone increase to ODS decrease.

The goal of this work is to use multi-decadal observations of source and reservoir trace gases from satellite and groundbased instruments, along with a hindcast simulation from the Global Modeling Initiative chemistry transport model (GMI CTM), driven by meteorological fields from MERRA version 2 (MERRA-2), to explore extratropical variability and trends in lower-stratospheric transport and mean age between 1990 and 2015. This work establishes a framework for the use of ground-based and satellite observations of constituents other than ozone to identify and quantify long-term changes in the residual circulation. We argue that the simulation must reproduce the interannual and longer-timescale variability seen in the observed data records to confirm the realism of trends in the simulated mean age. We consider two overarching questions:

1. Do comparisons of modeled and observed trace gases support the trends in circulation and mean age inferred from reanalyses?
2. Are the ongoing sparse data sets available from the early 1990s sufficient to characterize multiyear variability and thereby provide more robust trend estimates?

Observations used in this work include columns of reservoir gases at several NDACC stations ( 1990-ongoing), profiles from the Halogen Occultation Experiment (HALOE) on the Upper Atmosphere Research Satellite (UARS) (1991-2005) and near-global profile data sets from the MLS on EOS Aura (mid-2004-ongoing); these are described in Sect 2. Models are discussed in Sect. 3. Comparisons of simulations with observations and their relationship to simulated mean age are found in Sect. 4. Discussion and conclusions follow in Sect. 5 .

\section{Observations}

\subsection{Network for the detection of atmospheric composition change}

Here we use total column measurements of $\mathrm{HCl}$ described by Mahieu et al. (2014) and version $7 \mathrm{HNO}_{3}$ (Ronsmans et al., 2016) from Fourier transform infrared (FTIR) instruments at two stations (Jungfraujoch, Switzerland, $46.6^{\circ} \mathrm{N}$, $7.98^{\circ} \mathrm{E}$, and Lauder, New Zealand, $\left.45.0^{\circ} \mathrm{S}, 169.7^{\circ} \mathrm{E}\right)$. Both of these stations belong to the NDACC (http://www. ndacc.org). The data, courtesy of Emmanual Mahieu (PI for the NDACC Jungfraujoch station) and Dan Smale (PI for the NDACC Lauder station), are publicly available through an anonymous FTP at ftp://ftp.cpc.ncep.noaa. gov/ndacc/station/jungfrau/ and ftp://ftp.cpc.ncep.noaa.gov/ ndacc/station/lauder/. This analysis is limited to midlatitudes, and these stations are chosen for comparison with the simulation because of the length of their records ( 1987ongoing at Jungfraujoch and $\sim 1990$-ongoing at Lauder). The comparison of the simulation with data from other northern midlatitude stations is similar to that reported here but is not discussed here because the length of record is important to this analysis.

\subsection{UARS Halogen Occultation Experiment (HALOE)}

HALOE on UARS (Russell III et al., 1993) measured profiles of ozone and other gases including methane $\left(\mathrm{CH}_{4}\right)$ using solar occultation from September 1991 until the end of the mission in late 2005. HALOE nominally obtained 15 sunrise and sunset profiles daily, providing near-global coverage in about a month. HALOE obtained profiles between 270 and 320 days $\mathrm{yr}^{-1}$ between 1992 and 1995, but operational issues limited measurements to about 180 days per year for 1996 until the end of the mission in November 2005. These issues precluded observations during some seasons at specific latitude bands later in the mission. We take this into account by restricting comparisons with the simulation to winter between 35 and $55^{\circ}$ latitude, where the number of observations 
per year is nearly constant in both hemispheres. Profiles used here are retrieved using algorithm version 19 and interpolated to 13 UARS standard pressure levels starting at $100 \mathrm{hPa}$ (i.e., $p_{i}=100 \cdot \exp (i / 6)$, where $i$ is an integer). The combined systematic and random uncertainty of single $\mathrm{CH}_{4}$ profiles in the lower stratosphere is $11-19 \%$ (Grooß and Russell III, 2005).

\subsection{Aura Microwave Limb Sounder (MLS)}

Livesey et al. (2017) describe the version 4.2 (v4) MLS data products, their precision, accuracy and screening procedures to identify and eliminate profiles that are not recommended for scientific use. Here we use MLS observations for 2005-2015 for the source gas nitrous oxide $\left(\mathrm{N}_{2} \mathrm{O}\right)$. The v4 data set retrieved from the band $12640 \mathrm{GHz}\left(\mathrm{N}_{2} \mathrm{O}-\right.$ 640 ) is scientifically useful from 100 to $0.46 \mathrm{hPa}$. This data set begins shortly after launch but ends in mid-2013 due to band failure. The second $\mathrm{v} 4$ data set, retrieved from band $3190 \mathrm{GHz}\left(\mathrm{N}_{2} \mathrm{O}-190\right)$, begins shortly after launch and is ongoing. Aura MLS provides $\sim 3495$ profiles daily between $81^{\circ} \mathrm{S}$ and $81^{\circ} \mathrm{N}$; data are averaged in $2^{\circ}$ latitude bins (3060 profiles per bin after screening), reducing precision uncertainty. Monthly, seasonal and annual averages are compared with simulations that are described below. The highest pressure level for useful measurements is $68 \mathrm{hPa}$ for $\mathrm{N}_{2} \mathrm{O}$ 190 compared with $100 \mathrm{hPa}$ for $\mathrm{N}_{2} \mathrm{O}-640$. In addition, percentage differences $\left(\mathrm{N}_{2} \mathrm{O}-190-\mathrm{N}_{2} \mathrm{O}-640\right) / \mathrm{N}_{2} \mathrm{O}-640 \cdot 100$ vary both seasonally and temporally at middle latitudes. For example, $\mathrm{NH}$ monthly zonal mean differences at $68 \mathrm{hPa}$ are between 4 and $8 \%$ in 2005 and decrease to $0-5 \%$ by 2012 , with greater temporal dependence during winter months. We limit comparisons with simulated $\mathrm{N}_{2} \mathrm{O}$ to $46.4 \mathrm{hPa}$ and lower pressures where the bias and its temporal dependence are smaller.

\section{Models}

\subsection{GMI CTM}

A GMI CTM hindcast simulation was integrated in 1 January 1980-2015 using MERRA-2 meteorological fields (Gelaro et al., 2017). MERRA-2 ingests recent satellite observations and uses an improved GCM (Molod et al., 2015) compared with MERRA (Rienecker et al., 2011). This GMI CTM simulation has $2^{\circ}$ latitude $\times 2.5^{\circ}$ longitude horizontal resolution and 72 vertical levels with $\sim 1 \mathrm{~km}$ resolution between 300 and $10 \mathrm{hPa}$. Details of a similar GMI CTM simulation using the earlier MERRA fields at $1^{\circ}$ latitude $\times 1.25^{\circ}$ longitude resolution are found in Strahan et al. (2013) and references therein. Reaction rates and cross sections are from the JPL evaluation 18 (Burkholder et al., 2015). Surface mixing ratio boundary conditions for all organic halogen and long-lived source gases follow the WMO A1 2010 and RCP 8.5 scenarios, respectively, and include $5 \mathrm{ppt}$ of additional $\mathrm{CH}_{3} \mathrm{Br}$ to account for bromine from short-lived source gases. Time-dependent stratospheric aerosols come from International Global Atmospheric Chemistry (IGAC) as prescribed for the SPARC Chemistry-Climate Model Initiative (CCMI) simulations. The simulation was initialized with December 1979 MERRA-2 meteorological fields using source gas and reservoir constituent fields from a prior simulation. The same MERRA-2 meteorological fields were used to integrate a clock tracer. The clock tracer is a linearly increasing conservative transport tracer forced at the two lowest model levels and has no atmospheric losses. It is always reset to the current date at the surface.

\subsection{GEOSCCM}

The Goddard Earth Observing System chemistry-climate model (GEOSCCM) couples the GEOS version 5 GCM (Rienecker et al., 2008; Molod et al., 2012) to the GMI stratosphere-troposphere chemical mechanism (Duncan et al., 2007; Strahan et al., 2007; Oman et al., 2013). The simulation used is run on the cubed sphere at $\mathrm{c} 48$ resolution, equivalent to a $2^{\circ}$ horizontal resolution, with the same vertical layers as GMI CTM. The surface mixing ratio boundary conditions are the same, except GEOSCCM uses the WMO A1 2014 halogen scenario instead of the A1 2010 used in the GMI CTM (these are very similar). Reaction rates and cross sections are the same as described for the GMI CTM. Observed sea surface temperatures and sea ice concentrations are also used to force this free-running simulation (Rayner et al., 2003).

\section{Results}

The global daily observations of the long-lived tracer $\mathrm{N}_{2} \mathrm{O}$ obtained from MLS are ideal for determining whether circulation trends inferred from analyses and/or from simulated age of air trends are consistent with observations. The MLS data set began in mid-2004 and is ongoing, but the projected changes in the BDC are multi-decadal. We therefore consider whether the sparse data sets available from the early 1990s are sufficient to characterize multi-annual variations, piecing together space-based observations from UARS HALOE and the multi-decadal ground-based column measurements of $\mathrm{HNO}_{3}$ and $\mathrm{HCl}$. For 2005 onward we test whether information from the ground-based column measurements is consistent with that obtained from MLS.

The first step towards meeting these goals is to examine the relationships between tracer and reservoir species and the mean age as produced by simulations using the GMI CTM and the GEOSCCM (Sect. 4.1). Our focus in Sect. 4.2 is to test whether the simulated changes track the observations of $\mathrm{CH}_{4}$ (UARS HALOE), $\mathrm{N}_{2} \mathrm{O}$ (Aura MLS), and of reservoir gases $\mathrm{HCl}$ and $\mathrm{HNO}_{3}$ from 1987 to present (NDACC groundbased column measurements). 


\subsection{Relationships among simulated age, $\mathrm{N}_{2} \mathrm{O}, \mathrm{CH}_{4}$ and reservoir gases}

\subsubsection{Source gases $\mathrm{N}_{2} \mathrm{O}$ and $\mathrm{CH}_{4}$}

Strahan et al. (2011) show that $\mathrm{N}_{2} \mathrm{O}$ observations from ACEFTS are anticorrelated with mean age observations for $\mathrm{N}_{2} \mathrm{O}$ values less than $150 \mathrm{ppbv}$ and mean age less than 4.5 years. Here we focus on the relationship between annual mean values to emphasize interannual and longer-timescale variability in circulation, noting that peak-to-peak seasonal variations in $\mathrm{N}_{2} \mathrm{O}$ and $\mathrm{CH}_{4}(\sim 10 \%$ of their respective means) and age ( $\sim 20 \%$ of the mean) are also anticorrelated (not shown). Examples of the evolution of annual mean age, $\mathrm{N}_{2} \mathrm{O}$ and $\mathrm{CH}_{4}$ in the GMI CTM, driven by MERRA-2 winds, show that mean age is anticorrelated with both $\mathrm{N}_{2} \mathrm{O}$ and $\mathrm{CH}_{4}$ (Fig. 1a and b).

The GMI CTM results show a large $\mathrm{N}_{2} \mathrm{O}$ increase between $\sim 1987$ and $\sim 1995$ in the northern midlatitudes, followed by a decrease from 2002 to 2004 through 2010 and another increase from 2010 to 2013. These are indicators of multiyear variability in MERRA-2 transport. The evolution of $\mathrm{CH}_{4}$ parallels that of $\mathrm{N}_{2} \mathrm{O}$ after about 1997 . The relationship between these tracers and age is similar in the $\mathrm{SH}$, with shorter periods of smaller increases or decreases in both tracers compared with the $\mathrm{NH}$. Annual mean $\mathrm{N}_{2} \mathrm{O}$ changes are generally reflected in the time series of annual mean age; the correlation coefficients between $\mathrm{N}_{2} \mathrm{O}$ and mean age for this example are $-0.77(\mathrm{NH})$ and $-0.66(\mathrm{SH})$.

Comparison of the evolution of mean age, $\mathrm{N}_{2} \mathrm{O}$ and $\mathrm{CH}_{4}$ in the GMI CTM (Fig. 1a and b) with that in the GEOSCCM (Fig. 1c and d) illuminates dynamical differences between the models as the simulations use the same boundary conditions for these gases. GEOSCCM changes in $\mathrm{N}_{2} \mathrm{O}$ and $\mathrm{CH}_{4}$ are reflected in the time series of mean age (correlation coefficients between annually averaged $\mathrm{N}_{2} \mathrm{O}$ and age are -0.91 in the $\mathrm{NH}$ and -0.96 in the $\mathrm{SH}$ ), but the multiyear variability is smaller. The percentage change per decade is calculated for successive 10-year periods beginning in 1980 for both hemispheres (Fig. 1e and f). In GEOSCCM, the rate of $\mathrm{N}_{2} \mathrm{O}$ increase in the extratropics is always close to the tropical rate of increase of $\sim 2.6 \%$ decade $^{-1}$, with a small signature of the effect of the Pinatubo aerosols on the circulation. In contrast, the decadal rate of change in the GMI CTM extratropics may be 2-3 times greater or of the opposite sign compared with the rate of increase at the tropical tropopause (the same in both simulations as it is controlled by the boundary condition).
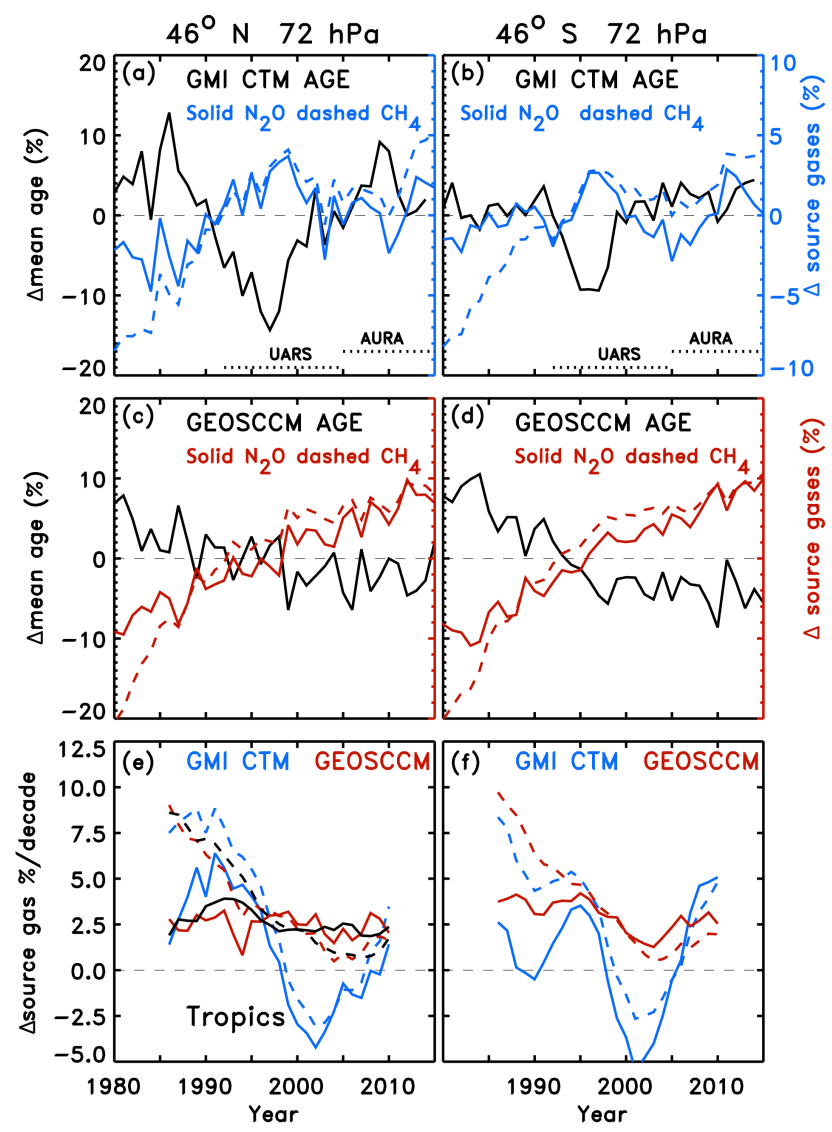

Figure 1. The GMI CTM differences from the 1980-2015 mean for mean age (black), $\mathrm{N}_{2} \mathrm{O}$ (blue) and $\mathrm{CH}_{4}$ (blue dashed) at $72 \mathrm{hPa}$ for (a) $46^{\circ} \mathrm{N}$ and (b) $46^{\circ} \mathrm{S}$. The GEOSCCM differences from the 1980-2015 mean for mean age (black), $\mathrm{N}_{2} \mathrm{O}$ (red) and $\mathrm{CH}_{4}$ (red dashed) at $72 \mathrm{hPa}$ for (c) $46^{\circ} \mathrm{N}$ and (d) $46^{\circ} \mathrm{S}$. Trends calculated for successive 10-year periods at $72 \mathrm{hPa}$ are shown for $\mathrm{N}_{2} \mathrm{O}$ (blue, GMI CTM; red, GEOSCCM) and $\mathrm{CH}_{4}$ (blue dashed, GMI CTM; red dashed, GEOSCCM) at (e) $46^{\circ} \mathrm{N}$ and (f) $46^{\circ} \mathrm{S}$. Tropical trends at $100 \mathrm{hPa}$ (black, $\mathrm{N}_{2} \mathrm{O}$; black dashed, $\mathrm{CH}_{4}$ ) are shown in (e). They are the same for both simulations and reflect the boundary conditions.

\subsubsection{Mean age and fractional release}

The age spectrum for a stratospheric air parcel is the distribution of transit times between entry to the stratosphere and the parcel location for each of the elements that comprise the parcel. The mean age is the average of this distribution, and comparisons of simulated mean age with that obtained from measurements such as $\mathrm{SF}_{6}$ (a long-lived trace gas that is increasing in the troposphere) provide information about the realism of the advective and mixing processes that control the parcel paths. Hall et al. (1999) used mean age comparisons to show lack of realism in the transport produced by various models that participated in Model and Measurements Intercomparison II (Park et al., 1999). Hall (2000) and Schoeberl et al. (2000) used trajectory calculations to show 
that, on average, the oldest elements have risen to highest altitudes; thus, evidence of loss of a long-lived gas in a parcel found in the lower stratosphere indicates that the age spectrum includes parcel elements that have experienced high altitude where source gas destruction occurs. These older elements of the age spectrum contribute to the mean age and determine the amount of destruction of long-lived gases. This relationship between the oldest elements of the age spectrum and the probability of destruction leads to compact, inverse relationships between mean age and gases with tropospheric sources. Indeed, aircraft observations show that the destruction of long-lived gases including chlorofluorocarbons, $\mathrm{N}_{2} \mathrm{O}$ and $\mathrm{CH}_{4}$ is related to the mean age obtained from $\mathrm{SF}_{6}$. Schauffler et al. (2003) use aircraft observations to compute the fractional release $f_{\mathrm{r}}$ :

$f_{\mathrm{r}}=\left(1-\frac{X(x)}{X_{i}}\right)$

where $X(x)$ is the mixing ratio of a source gas in a parcel at location $x$ (latitude, altitude, pressure, time) and $\mathrm{X}_{i}$ is the mixing ratio at entry to the stratosphere, finding a near-linear relationship between $f_{\mathrm{r}}$ and the $\mathrm{SF}_{6}$ mean age. Waugh and Hall (2002, and references therein) discuss the relationship between tracer distributions and transport timescales in the stratosphere, noting the connection between the BDC and the wave-driven quasi-horizontal mixing that controls distributions of stratospheric trace gases. Because the fractional release depends on destruction of the source gas and therefore on the portion of the age spectrum that reaches high altitude where destruction is possible, the relationship between fractional release and mean age is a stronger test of the realism of simulated transport than the simple comparisons of mean age distributions. The older elements of the age spectrum that contribute to the mean age make the largest contribution to the fractional release. Mean age is negatively correlated with source gases and positively correlated with the products of their destruction (e.g., $\mathrm{HCl}$ and $\mathrm{HNO}_{3}$ ).

In GEOSCCM the BDC is fully consistent with the planetary wave breaking that results in horizontal mixing and plays a role in driving the BDC. This consistency is not guaranteed in the MERRA-2 fields. Comparison of fractional release and its relationship to mean age with values obtained from observations tests the balance between horizontal mixing and vertical transport. Waugh et al. (2007) apply these concepts to the simulated amounts of inorganic chlorine $\left(\mathrm{Cl}_{y}\right)$ released from source gases in a CTM using different grid resolution and meteorological fields, finding large differences in $\mathrm{Cl}_{y}$ for the same mean age. Within the same CTM, different meteorological fields or different implementation of meteorological fields may produce the same mean age but different values for the fractional release because the mean transport pathways differ.

In GMI CTM the fractional release of $\mathrm{N}_{2} \mathrm{O}$ for fixed mean age varies substantially between 1990 and 2000 in both hemispheres (Fig. 2a and b). In contrast, in GEOSCCM the frac-

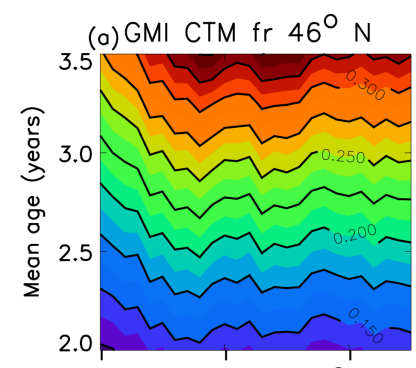

(b) GMI CTM fr $46^{\circ} \mathrm{S}$
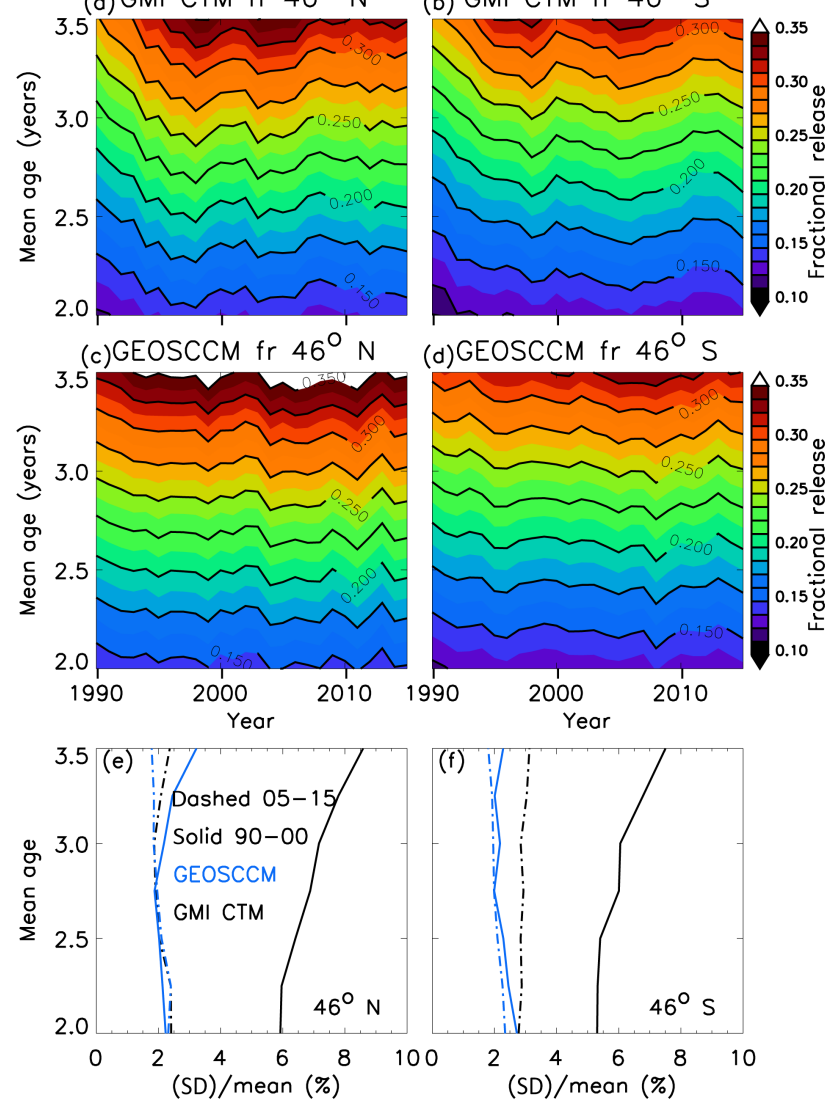

Figure 2. Contours of the evolution of $\mathrm{N}_{2} \mathrm{O}$ fractional release simulated by GMI CTM for 1990-2015 as a function of mean age at (a) $46^{\circ} \mathrm{N}$ and (b) $46^{\circ} \mathrm{S}$. Same for the GEOSCCM at (c) $46^{\circ} \mathrm{N}$ and (d) $46^{\circ} \mathrm{S}$. The ratio of the standard deviation of the $\mathrm{N}_{2} \mathrm{O}$ fractional release to the mean value from GMI CTM (black) and from GEOSCCM (blue) averaged from 1990 to 2000 (solid) and from 2005 to 2015 at (e) $46^{\circ} \mathrm{N}$ and (f) $46^{\circ} \mathrm{S}$.

tional release at the fixed mean age varies slowly (Fig. 2c and $d)$. The changing relationship between fractional release and mean age in the GMI simulation reveals decadal variations in the relationship between horizontal and vertical transport processes in MERRA-2. After about 2000, the small variations in $f_{\mathrm{r}}$ for fixed mean age in GMI CTM are comparable to the variations obtained throughout the period for GEOSCCM. We illustrate this by comparing the ratio of the $f_{\mathrm{r}}$ standard deviation to its mean for 19902000 and 2005-2015 for each simulation for both hemispheres (Fig. 2e and f). In GEOSCCM the ratio is about $2 \%$ for both time periods and for both hemispheres. For GMI CTM the ratio for 1990-2000 is between 6 and $8 \%$ for the age range 2-3.5 years in both hemispheres. For 2005-2015 the GMI CTM ratio is comparable to that obtained from GEOSCCM, although still larger than GEOSCCM in the SH. The smaller values of $f_{\mathrm{r}}$ at the fixed mean age found during the early 1990s suggest that the balance between hori- 
zontal and vertical transport processes up until about 2000 is substantially different in both hemispheres in the first half of the 1990 s than in subsequent years. This changing relationship contributes to the lower correlations of mean age with long-lived tracers in GMI CTM compared with GEOSCCM noted in Sect. 4.1.1 and also affects the relationship of mean age with reservoir gases discussed below.

\subsubsection{Reservoir gases $\mathrm{HCl}$ and $\mathrm{HNO}_{3}$}

Hydrochloric acid is the most abundant of the chlorine product species throughout the stratosphere, and more than $80 \%$ of the $\mathrm{HCl}$ column resides below $20 \mathrm{hPa}$. The sources of $\mathrm{HCl}$ increased by $\sim 5 \% \mathrm{yr}^{-1}$ up until about 1992 but leveled off during the late 1990s. The long-lived gases $\mathrm{CFCl}_{3}$ and $\mathrm{CF}_{2} \mathrm{Cl}_{2}$ have been decreasing slowly since $\sim 2000$ $\left(<1 \% \mathrm{yr}^{-1}\right)$ due to cessation of ODS production as a result of the Montreal Protocol and its amendments. Methyl chloroform $\left(\mathrm{CH}_{3} \mathrm{CCl}_{3}\right)$ is shorter lived and contributed about $\sim 15 \%$ of total inorganic chlorine in the lower stratosphere in 1995, decreasing rapidly thereafter. Prior to $\sim 2000$, growth of the $\mathrm{HCl}$ column and the $\mathrm{HCl}$ lower-stratospheric mixing ratio was controlled by the rapid growth of the source gases.

After $\sim 2000$, the simulated evolution of lowerstratospheric $\mathrm{HCl}$ and its column broadly matches mean age in both hemispheres (Fig. 3), although neither is a perfect surrogate for mean age variability at a particular level. Multiyear changes in the midlatitude $\mathrm{HCl}$ columns that are larger or opposite in sign to the source gas decrease reflect changes in the residual circulation (Mahieu et al., 2014). This is seen in the SH, where simulated column decreases are more rapid than can be accounted for by the decrease in source gases between 2005 and 2011. During this period the SH mean age decreases throughout the lower stratosphere (maximum rate of decrease $1 \% \mathrm{yr}^{-1}$ at $100 \mathrm{hPa}$ ), contributing to the decrease in simulated $\mathrm{HCl}$ column.

Nitric acid is similar to $\mathrm{HCl}$ in that both are produced from radicals released by destruction of tropospheric source gases in the upper stratosphere. It is the dominant component of total odd nitrogen $\left(\mathrm{NO}_{y}\right)$ between the tropopause and $\sim 50 \mathrm{hPa}$, poleward of about $40^{\circ}$ in both hemispheres. Lower-stratospheric $\mathrm{N}_{2} \mathrm{O}$ is anticorrelated with $\mathrm{NO}_{y}$ and also with $\mathrm{HNO}_{3}$ during winter when $\mathrm{HNO}_{3}$ is $\sim 90 \%$ of $\mathrm{NO}_{y}$. The stratosphere below $50 \mathrm{hPa}$ contains $\sim 80 \%$ of the total winter column $\mathrm{HNO}_{3}$. Except when the lower-stratospheric aerosol layer is enhanced by a Pinatubo-type volcanic eruption, a "trend" in the residual circulation may be identified by an increase in middle-latitude $\mathrm{HNO}_{3}$ columns that is faster or slower than the trend in $\mathrm{N}_{2} \mathrm{O}$ increase $\left(\sim 0.3 \% \mathrm{yr}^{-1}\right)$ for several consecutive years. The $\mathrm{HNO}_{3}$ column, lowerstratospheric $\mathrm{HNO}_{3}$ mixing ratio and the mean age simulated using GMI CTM track one another at middle latitudes in both hemispheres starting in 1993, about 18 months after the eruption of Mt. Pinatubo (Fig. 4).
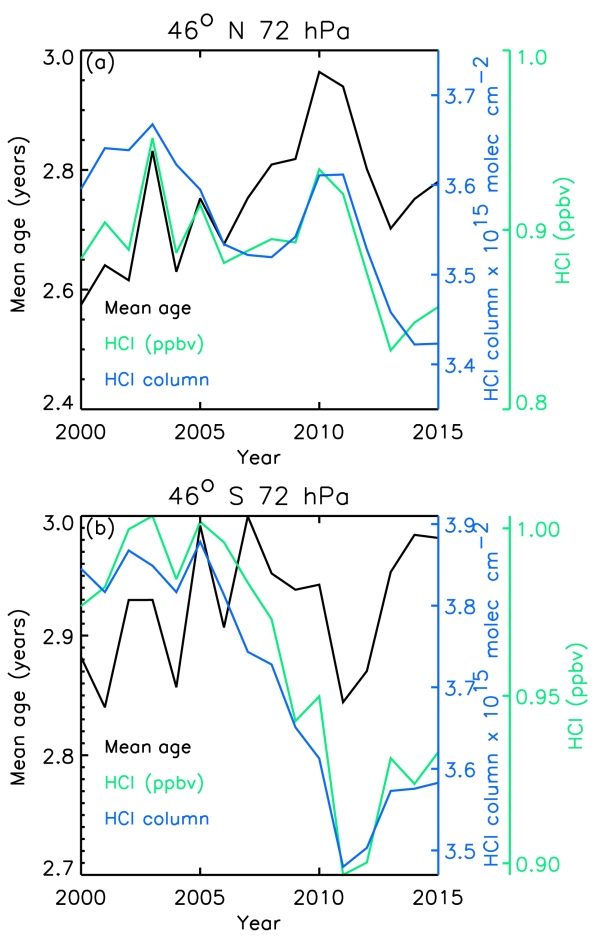

Figure 3. The evolution of the GMI CTM $\mathrm{HCl}$ mixing ratio (green) and mean age (black) at $72 \mathrm{hPa}$ and the $\mathrm{HCl}$ column (blue) at (a) $46^{\circ} \mathrm{N}$ and (b) $46^{\circ} \mathrm{S}$. The $\mathrm{HCl}$ column is $N \times 10^{15}$ molecules per $\mathrm{cm}^{2}$, where $N$ is the right blue axis. The time interval begins in 2000 when the chlorine-containing source gases have stopped increasing or begun to decline.

Although neither the total column $\mathrm{HNO}_{3}$ or $\mathrm{HNO}_{3}$ mixing ratio at a particular level correlates perfectly with the mean age, Fig. 4 shows decadal-scale upward trends in both hemispheres in the $\mathrm{HNO}_{3}$ column, $\mathrm{HNO}_{3}$ mixing ratio and mean age for $\sim 1998$ to 2010. The simulated winter $\mathrm{HNO}_{3}$ mixing ratio and mean ages are correlated with levels above and below and with each other between 25 and $85 \mathrm{hPa}$. The column, mean age and lower-stratospheric mixing ratio are positively correlated throughout the middle latitudes of both hemispheres.

\subsection{Observations, GMI CTM simulation and mean age}

The relationships of constituents and mean age apparent in the GMI CTM simulation driven by MERRA-2 fields suggest that quantitative information about residual circulation change at middle latitudes can be obtained from existing and ongoing measurements. The following discussion considers the $\mathrm{NH}$ and $\mathrm{SH}$ separately. In each we compare the simulation with ground-based FTIR column measurements of reservoir gases $\mathrm{HCl}$ and $\mathrm{HNO}_{3}$, available from the early 1990s at some stations, with HALOE measurements of the source gas $\mathrm{CH}_{4}$ (1992-2005) and with Aura MLS measurements of $\mathrm{N}_{2} \mathrm{O}$ (2005-present). 

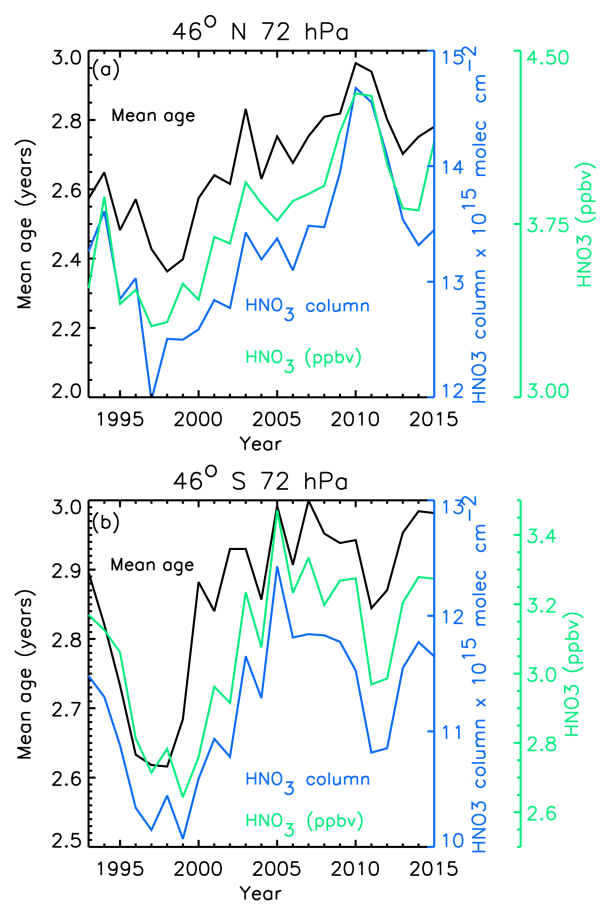

Figure 4. The evolution of the GMI CTM $\mathrm{HNO}_{3}$ mixing ratio (green) and mean age (black) at $72 \mathrm{hPa}$ and the $\mathrm{HNO}_{3}$ column (blue) at (a) $46^{\circ} \mathrm{N}$ and (b) $46^{\circ} \mathrm{S}$. The $\mathrm{HNO}_{3}$ column is $N \times 10^{15}$ molecules $\mathrm{cm}^{-2}$, where $N$ is the right blue axis. The time interval begins in 1993, about 18 months after the eruption of Mt. Pinatubo.

\subsubsection{Northern Hemisphere}

\section{NDACC - Jungfraujoch, Switzerland $\left(46.6^{\circ} \mathrm{N}, 7.98^{\circ} \mathrm{E}\right)$}

When sampled for the time and location of the observations, the NH NDACC column observations of $\mathrm{HNO}_{3}$ and $\mathrm{HCl}$ are highly correlated with the GMI columns (Fig. 5). These scatter plots include daily and seasonal variability as well as any trend in $\mathrm{HCl}$ and $\mathrm{HNO}_{3}$ due to trends in their source gases during the 26 years of measurements (1989-2014). The mean of the GMI HCl columns is within $3 \%$ of the mean of observations. The mean of the GMI $\mathrm{HNO}_{3}$ columns is $21 \%$ lower than the mean of the observations.

The time series of differences between observed and simulated $\mathrm{HCl}$ columns reveals a bias that changes over the course of the integration (Fig. 6a). The simulation is biased low before 2000 (positive differences) but has greatly reduced bias after $\sim 2004$. The time series of differences between observed and simulated $\mathrm{HNO}_{3}$ columns is similar to that of the $\mathrm{HCl}$ columns. The changing bias is demonstrated by comparing histograms of the percentage difference between observations and simulation for 1989-2004 and 2005-2015 (Fig. 6b and c). The bin size for each gas is equal to onethird of the standard deviation of all measurements. In both cases the distribution of differences for 1989-2004 is shifted
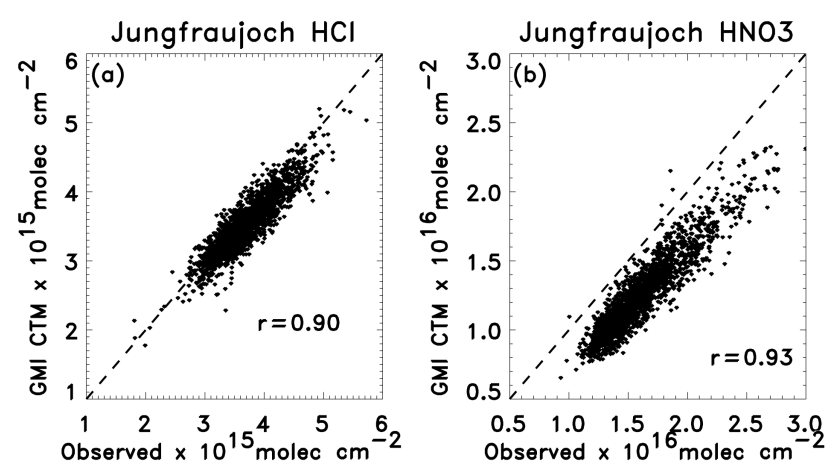

Figure 5. Simulated and observed columns 1989-2014 for (a) $\mathrm{HCl}$ and (b) $\mathrm{HNO}_{3}$. Both simulated species are highly correlated with the observations when the simulation is sampled for the location and days of the measurements.
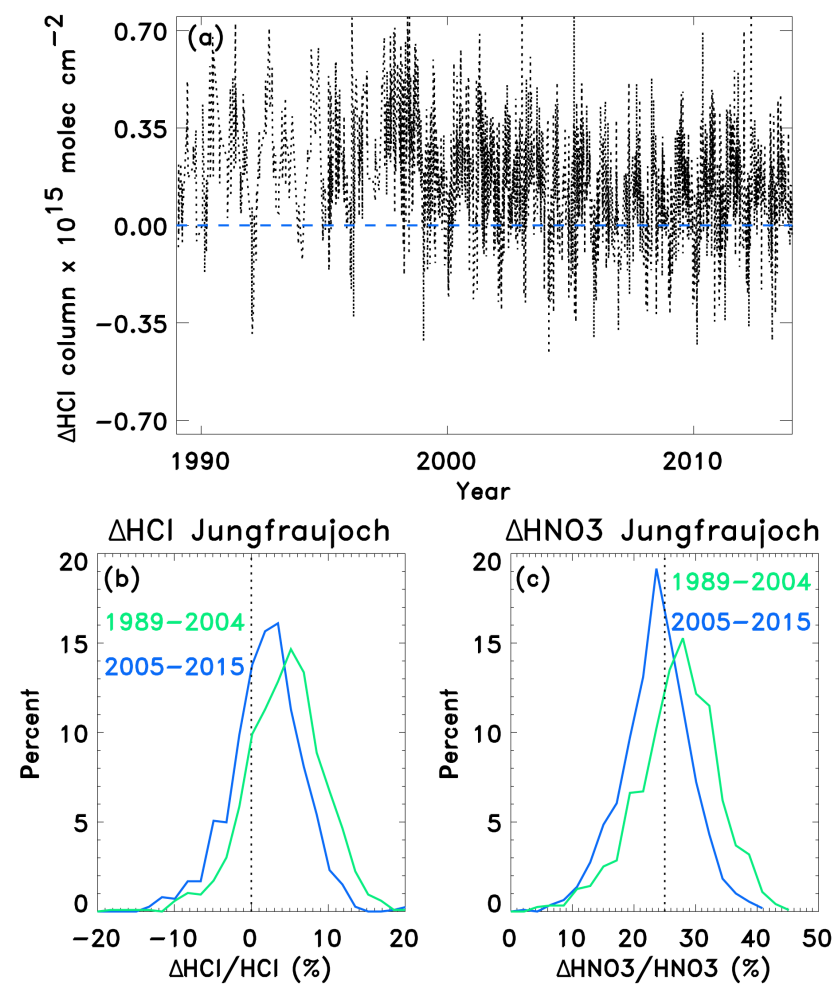

Figure 6. (a) Time series of the differences between observed and simulated $\mathrm{HCl}$ columns at Jungfraujoch. Histogram of the percentage differences for 1989-2004 (green) and 2005-2015 (blue) (b) for $\mathrm{HCl}$ and (c) $\mathrm{HNO}_{3}$.

towards the right compared with the distribution for 20052015. There are fewer observation days per year prior to 1996 (average 37, standard deviation - SD 24) than 1997 onward (average 95, SD 27), but subsampling later years to match the observation frequency and seasonality of early years does not change this result. The shift towards better agreement is not sensitive to the exact time interval (i.e., similar results are obtained comparing the distribution for 1989-2000 


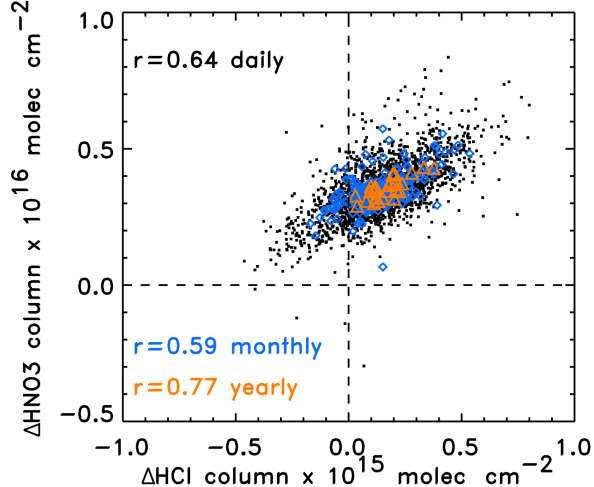

Figure 7. The differences between simulated and observed columns at Jungfraujoch for $\mathrm{HCl}$ are correlated with the differences for $\mathrm{HNO}_{3}$, whether considering daily average (black), monthly average (blue) or yearly average (orange) values.

with 2000-2015). We chose to emphasize 2005-2015 because Aura MLS obtained global data sets during this period.

Figure 7 shows that on days when both $\mathrm{HCl}$ and $\mathrm{HNO}_{3}$ are measured, the differences between measured and simulated $\mathrm{HNO}_{3}$ are strongly correlated with the differences between measured and simulated $\mathrm{HCl}$. This correlation is found whether daily, monthly or annual averaged timescales are considered. On the annual timescale, the correlation is found whether averaging all measurements for each gas each year or when averaging only measurements on days both gases were reported. We conclude that the similar time dependencies of the differences $\left(\triangle \mathrm{HCl}\right.$ and $\left.\Delta \mathrm{HNO}_{3}\right)$ are caused by substantial differences in the transport characteristics of MERRA-2 fields during the 1990s compared with the period 2004 and onward. The correlation between differences cannot be explained by photochemistry because unrelated processes control partitioning of the chlorine- and nitrogencontaining reservoir species in the lower stratosphere. Furthermore, this correlation holds even though anthropogenic chlorine source gases increased until $\sim 2000$ and declined thereafter, while the source gas $\mathrm{N}_{2} \mathrm{O}$ increased steadily for the entire period. Our conclusion is consistent with the change in the relationship between the fractional release and mean age found in the NH lower stratosphere (Fig. 2a and e). The lower values of fractional release during the 1990s are consistent with the shift in the distribution of $\mathrm{HCl}$ column differences from a low bias in the 1990s to a much smaller low bias after 2004. This also explains the shift in the distributions of $\mathrm{HNO}_{3}$, but does not explain the low bias in simulated $\mathrm{HNO}_{3}$ that remains after $2004(20 \%)$, when the difference between simulated and observed $\mathrm{HCl}$ is within experimental error.

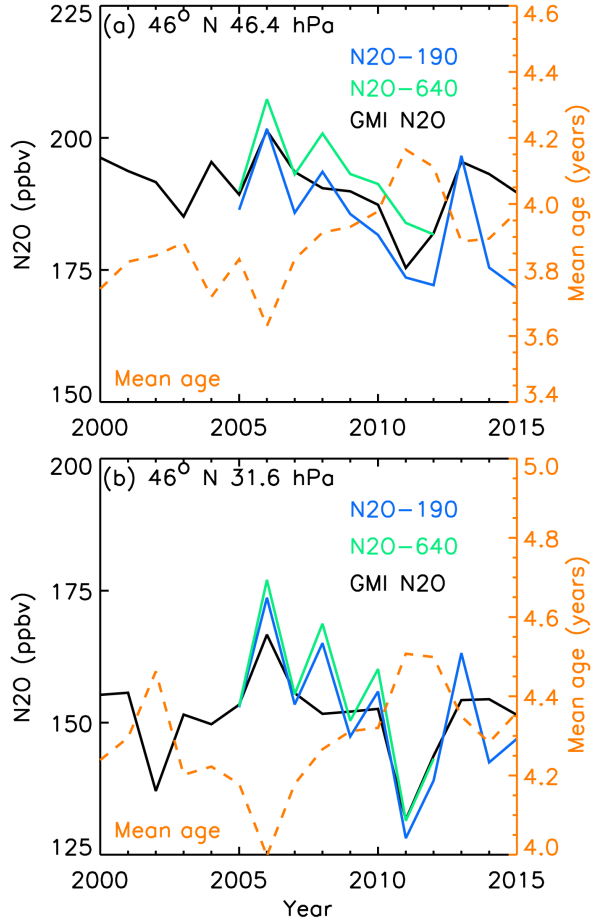

Figure 8. The $46^{\circ} \mathrm{N}$ annual zonal mean $\mathrm{N}_{2} \mathrm{O}$ in the GMI CTM (black), the MLS $\mathrm{N}_{2} \mathrm{O}-640$ (green), the MLS $\mathrm{N}_{2} \mathrm{O}-190$ (blue) and the mean age (orange dashed) at (a) $46.4 \mathrm{hPa}$ and (b) $31.6 \mathrm{hPa}$. The simulated $\mathrm{N}_{2} \mathrm{O}$ tracks the observed values and is anticorrelated with the mean age at both levels $(-0.86$ and -0.83 at 46.4 and $31.6 \mathrm{hPa}$, respectively).

\section{Aura MLS Northern Hemisphere}

As discussed in detail by Strahan et al. (2011), the mean age is a near-linear function of $\mathrm{N}_{2} \mathrm{O}$ for $\mathrm{N}_{2} \mathrm{O}$ values greater than about $\sim 150 \mathrm{ppbv}$ (about half the value at the tropical tropopause). Here we focus on midlatitude annual averages at two MLS levels (46.4 and $31.8 \mathrm{hPa}$ ), noting that the difference between the simulated and zonal mean MLS $\mathrm{N}_{2} \mathrm{O}$ ( $640 \mathrm{GHz}$ receiver) is less than $10 \%$ for MLS annual means greater than $150 \mathrm{ppbv}$. To emphasize multiyear variations, we compare simulated annual averages with observed values from both MLS $\mathrm{N}_{2} \mathrm{O}$ bands at $46^{\circ} \mathrm{N}$ at 46.4 and $32 \mathrm{hPa}$ (Fig. 8). There is a $6 \%$ bias between the annual means for $\mathrm{N}_{2} \mathrm{O}-190$ compared with $\mathrm{N}_{2} \mathrm{O}-640$ at $46.4 \mathrm{hPa}$. Simulated $\mathrm{N}_{2} \mathrm{O}$ agrees well with observations throughout the period and is strongly anticorrelated with the simulated mean age. The observed and simulated 2006-2011 decreases are accompanied by simulated increases in mean age, consistent with column increases in both $\mathrm{HCl}$ and $\mathrm{HNO}_{3}$ (Mahieu et al., 2014).

\section{UARS HALOE Northern Hemisphere}

Because HALOE sampling is not uniform, the simulation output is subsampled at the location and time of the HALOE measurements. We focus on January-February-March for 


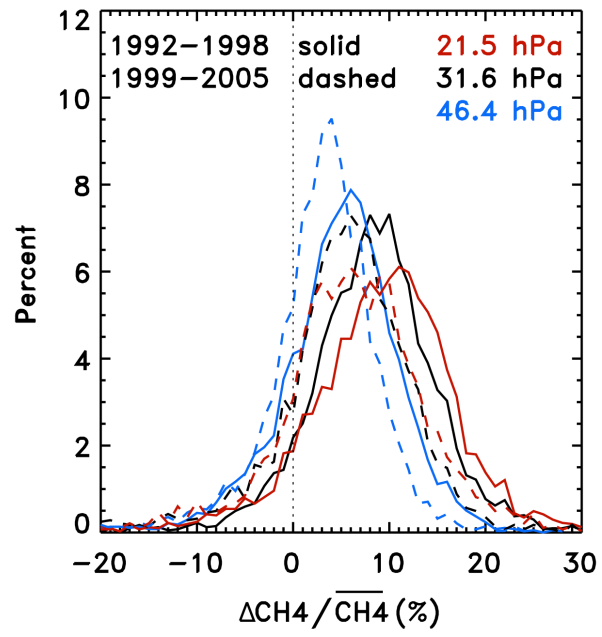

Figure 9. Histograms of percentage differences between HALOE and simulated $\mathrm{CH}_{4}$ at $46.4 \mathrm{hPa}$ (blue), $31.6 \mathrm{hPa}$ (black) and $21.4 \mathrm{hPa}$ (red) for all HALOE profiles between 35 and 55 . The distributions at all levels shift towards better agreement with observations for 1999-2005 compared with 1992-1998.

$35-55^{\circ} \mathrm{N}$ because the number of profiles obtained at midlatitudes during each winter is similar over the life of the mission (see Sect. 2.2).

Factors other than nonuniform sampling complicate the relationship of $\mathrm{HALOE} \mathrm{CH}_{4}$ with circulation and mean age. First, because aerosols from the eruption of Mt. Pinatubo interfere with HALOE measurements below $46 \mathrm{hPa}$ in 1992 and 1993, we focus on comparisons at 46.4, 31.6 and $21.5 \mathrm{hPa}$. Second, the rate of $\mathrm{CH}_{4}$ increase at the tropical tropopause (specified by the boundary condition) is variable and may be substantially larger, about the same or smaller than the rate of increase in $\mathrm{N}_{2} \mathrm{O}$ (Fig. 1). The rate of $\mathrm{CH}_{4}$ increase in the tropics at $100 \mathrm{hPa}$ is greater than $1 \% \mathrm{yr}^{-1}$ in 1979 , falls to less than $0.1 \% \mathrm{yr}^{-1}$ between 2000 and 2005 , and increases to $1 \% \mathrm{yr}^{-1}$ by the end of the integration. Assuming that the observationally derived boundary condition is correct, comparisons of observed and simulated $\mathrm{CH}_{4}$ test the fidelity of the transport. Finally, we note that normalized vertical and horizontal $\mathrm{CH}_{4}$ gradients are smaller than the $\mathrm{N}_{2} \mathrm{O}$ gradients, making $\mathrm{CH}_{4}$ less sensitive to circulation changes.

The differences between HALOE and simulated $\mathrm{CH}_{4}$ for 1992-1998 are compared with differences for 1999-2005 by examining histograms of the percentage differences for each time period at 46.4, 31.6 and $21.5 \mathrm{hPa}$ (Fig. 9). At all three levels, the distributions shift towards a smaller difference in the later time period. The observed and simulated values are positively correlated for 1992-1998 (between 0.7 and 0.8 ), but correlations are larger during the later period (slightly larger than 0.8 ). The larger differences during the earlier period are consistent with greater horizontal mixing

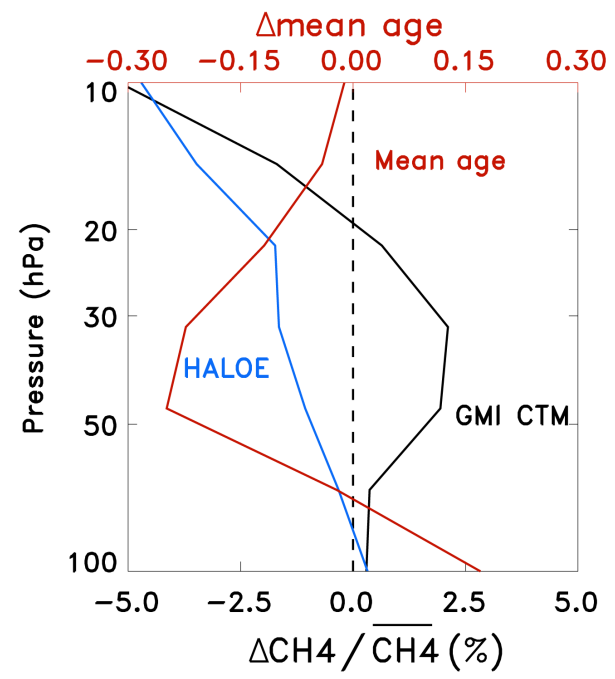

Figure 10. Percentage differences between 1994-1999 and 20002005 winter mean $\mathrm{CH}_{4}$ profiles at $35-55^{\circ} \mathrm{N}$ for HALOE (blue) and GMI CTM (black). The difference between the $35-55^{\circ} \mathrm{N}$ winter mean age profiles for the same periods is shown in red.

and with the unexpected time dependence in the relationship of fractional release and simulated mean age.

We look at observed and simulated $\mathrm{CH}_{4}$ changes over the period of the HALOE observations by computing the difference between 1994-1999 and 2000-2005 mean profiles (Fig. 10). The HALOE mean $\mathrm{CH}_{4}$ decreases between 68 and $10 \mathrm{hPa}$, whereas the GMI $\mathrm{CH}_{4}$ increases (Fig. 10a). The very small differences between HALOE and GMI at the two lowest levels suggest that the time dependence of the mixing ratio at stratospheric entry is realistic. The simulated mean ages for 2000-2005 are younger for $68-10 \mathrm{hPa}$ compared with 1994-1999, consistent with the increase in GMI $\mathrm{CH}_{4}$. However, the HALOE data do not support this decrease in mean age as produced by the MERRA- 2 meteorological fields.

To summarize the $\mathrm{NH}$ comparisons, the simulated columns of $\mathrm{HNO}_{3}$ and $\mathrm{HCl}$ follow NDACC observations at the Jungfraujoch station after $\sim 2000$ with higher fidelity than prior years. The simulated columns of both constituents are lower than the observed columns during the middle 1990s; this is consistent with lower values for fractional release for a given mean age in the 1990s compared with the 2000s (Fig. 2). The comparison of simulated $\mathrm{CH}_{4}$ with HALOE observations similarly shows that the age change produced by the GMI CTM using MERRA-2 meteorology between 68 and $\sim 20 \mathrm{hPa}$ during the 1990s is not realistic. The mean fractional release for fixed mean ages is larger after 2000 (Fig. 2a), indicating that after 2000 MERRA-2 transport pathways take more air parcels to higher altitudes than during the 1990s (Hall, 2000). The simulated long-lived species $\mathrm{HCl}, \mathrm{HNO}_{3}, \mathrm{CH}_{4}$ and $\mathrm{N}_{2} \mathrm{O}$ are all closer to the observations after 2000 , indicating that transport characteristics 

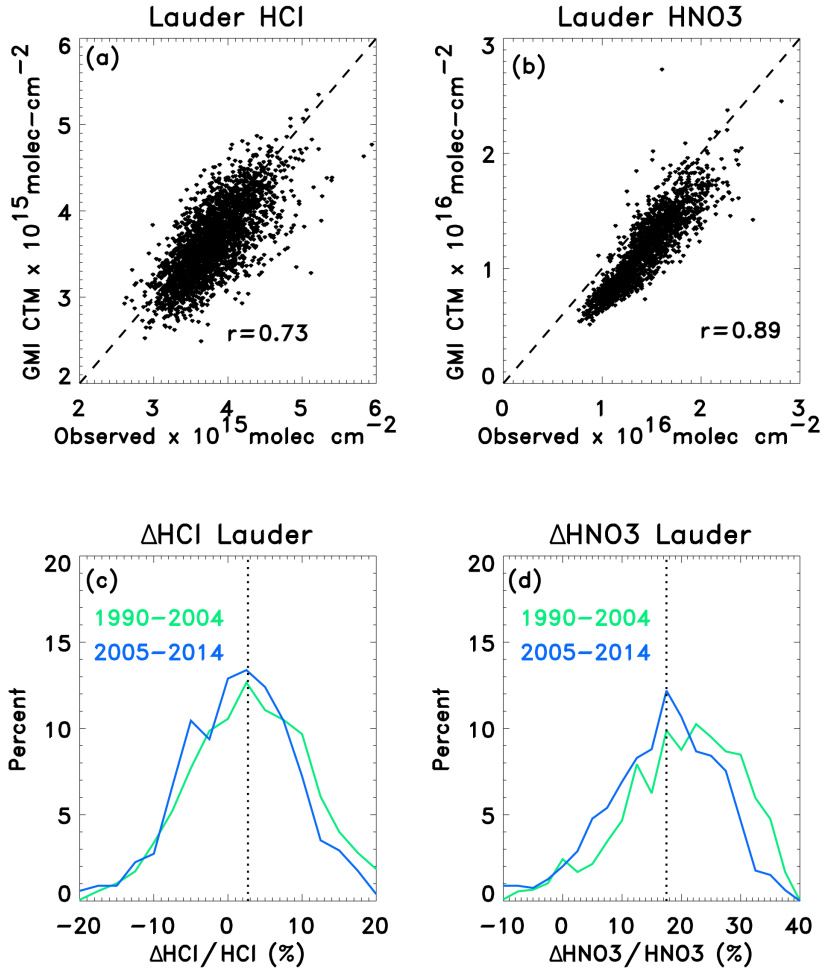

Figure 11. The GMI CTM and observed columns at Lauder station in 1990-2014 for (a) $\mathrm{HCl}$ and (b) $\mathrm{HNO}_{3}$. Histogram of the percentage difference between simulated and observed columns in 1990-2004 (blue) and 2005-2014 (green) for (c) $\mathrm{HCl}$ and (d) $\mathrm{HNO}_{3}$.

of the GMI CTM using MERRA-2 are more realistic in this period.

Together, the observations do not support the MERRA-2 mean age evolution before 2000, but do support the realism of the increase in northern midlatitude lower-stratospheric mean age between 2005 and 2011 following the quiescent period 2000-2004. The strong relationship between variability in simulated lower-stratospheric mean age, MLS $\mathrm{N}_{2} \mathrm{O}$ and the NDACC $\mathrm{HNO}_{3}$ columns demonstrates the value of these observations for evaluating the residual circulation and mixing in meteorological analyses. Furthermore, the duration of periods of positive or negative changes in the circulation shows that multi-decadal records are required to identify a geophysically significant trend in the stratospheric circulation.

\subsubsection{Southern Hemisphere}

\section{NDACC Lauder, New Zealand $\left(45.0^{\circ} \mathrm{S}, 169.7^{\circ} \mathrm{E}\right)$}

As for the NH Jungfraujoch station, the simulation is sampled for the time and location of the $\mathrm{HCl}$ and $\mathrm{HNO}_{3}$ column observations at the Lauder station. The simulated columns for both species are correlated with observations (Fig. 11a

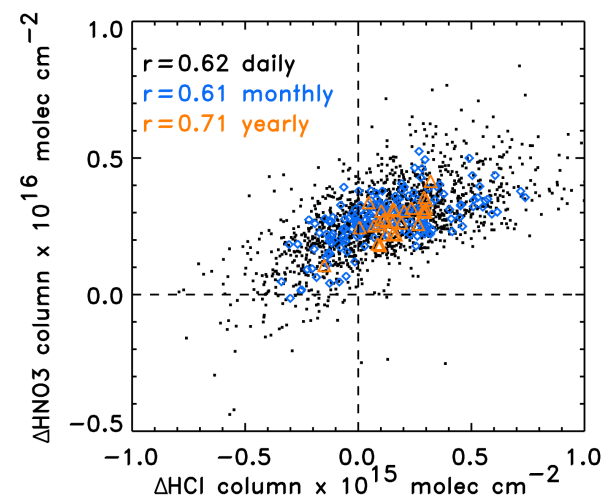

Figure 12. The differences between observed and simulated Lauder $\mathrm{HCl}$ columns are correlated with the differences between observed and simulated $\mathrm{HNO}_{3}$ columns, whether considering daily values (black), monthly averages (blue) or yearly averages (orange).

and b), although there is more scatter in the relationship between observed and simulated $\mathrm{HCl}$ columns evidenced by the lower SH correlation (0.73) compared with the NH (0.90). The mean bias between observations and simulation is less than $4 \%$ for $\mathrm{HCl}$ and about $18 \%$ for $\mathrm{HNO}_{3}$, comparable to the NH. The distributions of differences shift slightly towards better agreement for 2004-2014 compared with 1990-2004. The shifts are smaller than found for the NH.

Like the $\mathrm{NH}$, the differences between observed and simulated $\mathrm{HNO}_{3}$ columns are correlated with the differences between observed and simulated $\mathrm{HCl}$ columns (Fig. 12) for daily values $(r=0.62)$, monthly averages $(r=0.61)$ or annual averages $(r=0.71)$.

\section{Aura MLS Southern Hemisphere}

As expected, at middle latitudes the annual means of GMI $\mathrm{N}_{2} \mathrm{O}$ and mean age (shown at $46^{\circ} \mathrm{S}$ ) are correlated at 46.4 and $31.6 \mathrm{hPa}$ (Fig. 13). The GMI $\mathrm{N}_{2} \mathrm{O}$ tracks the observed $\mathrm{N}_{2} \mathrm{O}-640$ at both levels and $\mathrm{N}_{2} \mathrm{O}-190$ only at $31.6 \mathrm{hPa}$. At $31 \mathrm{hPa}$ the two retrievals maintain a near-constant bias as a function of time, whereas bias is year dependent at $46.4 \mathrm{hPa}$. At $46.4 \mathrm{hPa}$ the simulated $\mathrm{N}_{2} \mathrm{O}$ reflects some of the observed year-to-year differences and agrees better with $\mathrm{N}_{2} \mathrm{O}-640$, while at $31.6 \mathrm{hPa}$ it agrees very closely with $\mathrm{N}_{2} \mathrm{O}$ 190. At $31.6 \mathrm{hPa}$, both retrievals are consistent with the mean age changes between 2004 and 2015.

\subsubsection{UARS HALOE Southern Hemisphere}

We focus on SH winter months July-August-September for $35-55^{\circ} \mathrm{S}$ because the number of profiles obtained at midlatitudes during each winter is similar over the life of the mission (see Sect. 2.2). As in the NH, we compare the differences between HALOE and simulated $\mathrm{CH}_{4}$ for 1992-1998 with 1999-2005 by examining histograms of the percentage differences for each time period at $46.4,31.6$ and $21.5 \mathrm{hPa}$ 


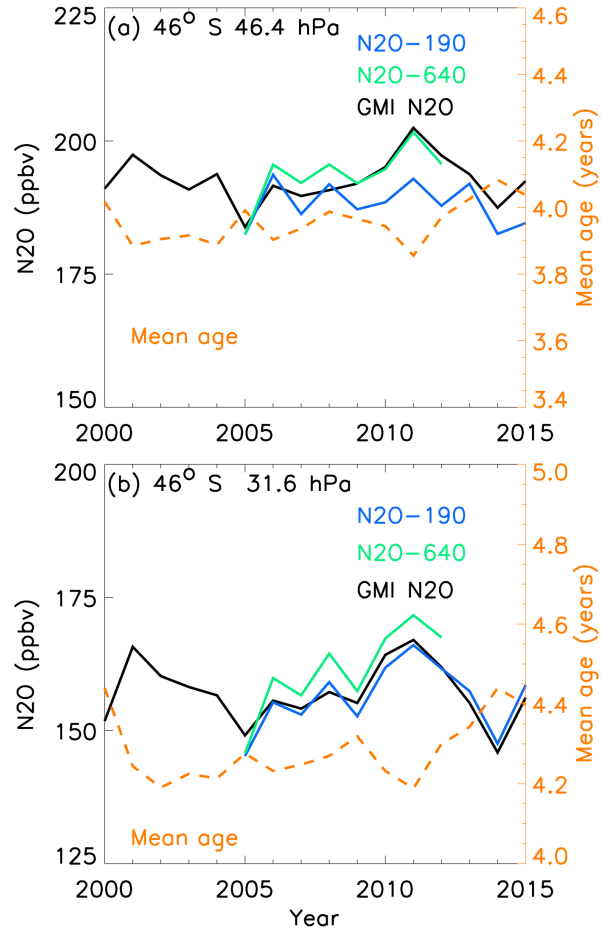

Figure 13. (a) The $46^{\circ} \mathrm{S}$ annual zonal mean $\mathrm{N}_{2} \mathrm{O}$ in the GMI CTM (black) follows MLS $\mathrm{N}_{2} \mathrm{O}-640$ (green) but not $\mathrm{N}_{2} \mathrm{O}-190$ (blue) at $46.4 \mathrm{hPa}$. The simulated $\mathrm{N}_{2} \mathrm{O}$ is anticorrelated with the mean age and with MLS $\mathrm{N}_{2} \mathrm{O}-640$. (b) The GMI CTM $\mathrm{N}_{2} \mathrm{O}$ follows both MLS products at $31.6 \mathrm{hPa}$ and is anticorrelated with mean age.

(Fig. 14). Again, the distributions shift towards smaller differences during the later time period. The observed and simulated values are positively correlated for 1992-1998 (0.630.78 on the three levels); correlations are nearly unchanged in the later period. As in the $\mathrm{NH}$, the comparison improves as the integration proceeds, consistent with the evolving relationship between mean age and fractional release discussed above.

As in Fig. 10, we look at mean age and observed and simulated $\mathrm{CH}_{4}$ changes over the period of the HALOE observations (Fig. 15). The age increase below $50 \mathrm{hPa}$ has little impact on the simulated profile change because the gradients are weak. The mean age for 2000-2005 is younger compared with 1994-1999 for 50-10 hPa. Both the observed and simulated profile changes are positive, consistent with the age decrease, but the simulated change is substantially larger than that observed for most of the profile, casting doubt on the realism of the simulated age decrease (Fig. 1b).

To summarize, comparison of constituent evolution from four data sets (NDACC $\mathrm{HNO}_{3}$ and $\mathrm{HCl}$ columns, HALOE $\mathrm{CH}_{4}$, Aura MLS $\mathrm{N}_{2} \mathrm{O}$ ) with the GMI CTM simulation leads us to similar conclusions in both hemispheres regarding MERRA-2 transport. Horizontal transport and mixing during the 1990s generally led to somewhat older mean age, but agreement with observations improves as the relation-

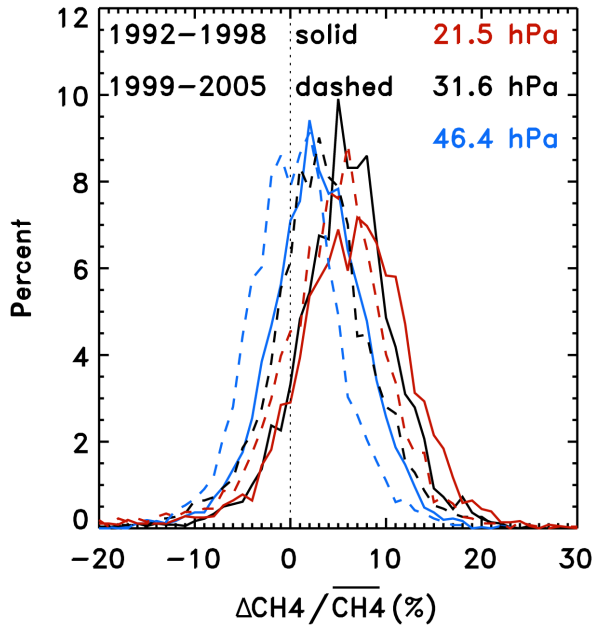

Figure 14. Histograms of percentage differences between HALOE and simulated $\mathrm{CH}_{4}$ at $46.4 \mathrm{hPa}$ (blue), $31.6 \mathrm{hPa}$ (black) and $21.4 \mathrm{hPa}$ (red) for all HALOE profiles between 35 and $55^{\circ} \mathrm{S}$ for $1992-$ 1998 (solid) and 1999-2005 (dashed).

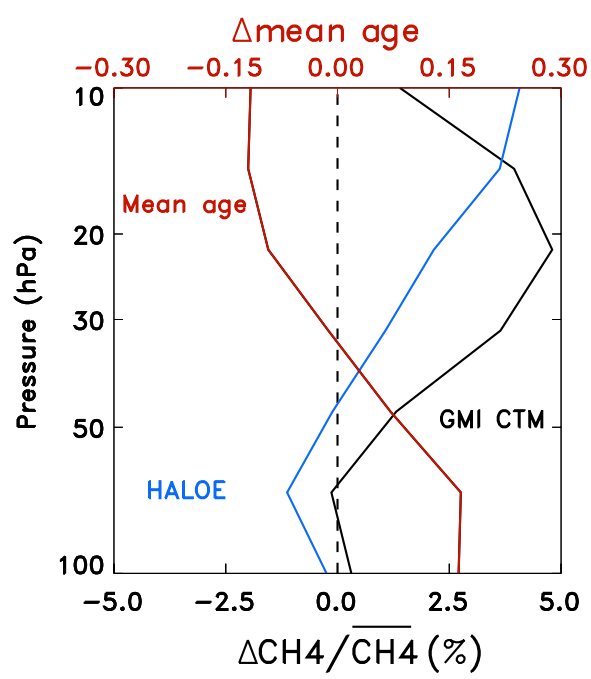

Figure 15. Percentage differences between 1994-1999 and 20002005 winter mean $\mathrm{CH}_{4}$ profiles at $35-55^{\circ} \mathrm{S}$ for HALOE (blue) and GMI CTM (black). The difference between the $35-55^{\circ} \mathrm{S}$ winter mean age profiles for the same periods is shown in red.

ship between mean age and fractional release evolves in the 2000s. This indicates that transport in the GMI CTM using MERRA-2 becomes more realistic as the simulation progresses. Lower fractional release for a given mean age leads to underestimates of the reservoir species during the 1990s. Overall, the differences between observed and simulated columns of $\mathrm{HCl}$ are correlated with the differences between observed and simulated $\mathrm{HNO}_{3}$, strongly indicating transport as their cause and casting doubt on MERRA-2-driven GMI CTM lower-stratospheric mean ages in the 1990s. In contrast, the agreement with MLS $\mathrm{N}_{2} \mathrm{O}$ during the Aura period, 
along with better agreement with observed $\mathrm{HCl}$ and $\mathrm{HNO}_{3}$ columns, indicates the realism of age variations obtained from 2005 onward.

\section{Discussion and conclusions}

Reanalysis data sets such as MERRA-2 depend on the data assimilation system, its general circulation model and the data sets that are ingested by the system. Global data sets are of limited duration, and even though the same system is used to produce a multi-decadal reanalysis, differences in the quality and type of data sets that make up the observing system are unavoidable (Gelaro et al., 2017). Such differences may lead to nonphysical trends in analysis products and in constituents simulated using reanalysis meteorological fields in frameworks such as the GMI CTM. Although the relationship between the fractional release and mean age is expected to change in the midlatitude lower stratosphere if the BDC strengthens due to climate change (Douglass et al., 2008), the observations are not consistent with the large changes in fractional release for fixed mean age obtained during the 1990s using GMI CTM compared with the changes in GEOSCCM.

Global observations of tracers such as $\mathrm{N}_{2} \mathrm{O}$, obtained by Aura MLS since mid-2004, are ideal for evaluating the transport circulation in reanalysis data sets. The comparisons of simulated and observed fields demonstrated here for the annual average midlatitudes in both hemispheres and in a previous work using MERRA during the Arctic winter (e.g., Strahan et al., 2016) attest to the realism of MERRA and MERRA-2 meteorological fields from 2004 to present. Apparent trends in constituents in both hemispheres, seen in MLS $\mathrm{N}_{2} \mathrm{O}$ and ground-based column measurements of $\mathrm{HNO}_{3}$ and $\mathrm{HCl}$, are consistent with the changes in the lowerstratospheric residual circulation that caused an increase in mean age between 2007 and 2011 in the $\mathrm{NH}$ accompanied by smaller and opposing transport and mean age changes in the SH (Mahieu et al., 2014).

For the 1990s, in contrast, comparison of the simulated values with HALOE $\mathrm{CH}_{4}$ and ground based columns reveals multiple issues in both hemispheres. The MERRA-2 circulation produces multiyear constituent trends that are not observed. The comparisons are markedly better after 2000 , strongly suggesting that differences in the observing system affect the MERRA-2 fields. The differences between observed and simulated $\mathrm{HCl}$ and $\mathrm{HNO}_{3}$ are correlated with each other whether considering daily, monthly or yearly averages, strongly suggesting that issues with transport produced by GMI CTM using MERRA-2 fields cause the differences during the 1990s. The change in the simulated relationship between the fractional release and the mean age between the 1990s compared with later years suggests a difference in the mean parcel paths such that the highest altitude reached by the older air in the 1990s is lower than in the 2000s. The underestimate of simulated $\mathrm{HNO}_{3}$ and $\mathrm{HCl}$ in the 1990s seen in Fig. 6 is consistent with fewer elements in the age spectrum experiencing altitudes high enough for rapid destruction of source gases.

Understanding and accounting for these time-varying residual circulation trends is necessary for many applications: (1) to identify the expected decrease in stratospheric inorganic chlorine as the chlorine source gases decrease due to the Montreal Protocol and its amendments; (2) to identify and quantify the expected increase in stratospheric ozone due to the chlorine decrease, separate from multiyear variability in dynamics and transport; (3) to characterize and quantify the change in the Brewer-Dobson circulation due to increasing greenhouse gases; and (4) to characterize and quantify the expected midlatitude increase in stratospheric ozone caused by the aforesaid change in Brewer-Dobson circulation. Because the comparisons of observed and simulated $\mathrm{HCl}$ and $\mathrm{HNO}_{3}$ columns are consistent with comparisons of observed and simulated fields of source gases (HALOE $\mathrm{CH}_{4}$, 1992-2005; MLS $\mathrm{N}_{2} \mathrm{O}$, 2005-ongoing), continuation of these column data sets provides a robust means to evaluate the transport and mean age produced by reanalysis products in offline models such as the GMI CTM, including their effects on stratospheric ozone. Finally, periods of positive or negative constituent trends due to transport variability may be 5 years or longer in both hemispheres; this observation supports the requirement for multi-decadal records in order to identify a geophysically significant trend in the stratospheric circulation.

Data availability. The NDACC data are publicly available through an anonymous FTP at ftp://ftp.cpc.ncep.noaa.gov/ndacc/station/ jungfrau/ and ftp://ftp.cpc.ncep.noaa.gov/ndacc/station/lauder/ (accessed 10 March 2017). The HALOE data (Russell III, 1999) and MLS data (Lambert et al., 2015) are obtained from the Goddard Earth Sciences Data and Information Services Center (GES DISC). The GMI CTM simulation is publicly available through an anonymous FTP https://gmi.gsfc.nasa.gov (accessed 10 March 2017).

Competing interests. The authors declare that they have no conflict of interest.

Special issue statement. This article is part of the special issue "Twenty-five years of operations of the Network for the Detection of Atmospheric Composition Change (NDACC) (AMT/ACP/ESSD inter-journal SI)". It is not associated with a conference.

Acknowledgements. We thank the NASA Atmospheric Composition Modeling and Analysis, Aura, and Modeling Analysis and Predictions programs for supporting this research. We also thank the NASA Center for Climate Simulation (NCCS) for providing high-performance computing resources. We thank Stephen Steenrod and Megan Damon for updates to and integration 
of the GMI chemistry transport model simulation used here. We thank Emmanuel Mahieu of the Institute of Astrophysics and Geophysics, University of Liège, for the Jungfraujoch FTIR data. The multi-decadal monitoring program of University of Liège at the Jungfraujoch station has been primarily supported by the Fonds (National) de la Recherche Scientifique (F.R.S.-FNRS) and Belgian Federal Science Policy Office (BELSPO) (both in Brussels, Belgium) and by the Global Atmosphere Watch programme of MeteoSwiss (GAW-CH). The International Foundation High Altitude Research Stations Jungfraujoch and Gornergrat (HFSJG, Bern) supported the facilities needed to perform the FTIR observations. We thank Dan Smale and the National Institute of Water and Atmospheric Research (NIWA) MIR-FTIR team for the Lauder FTIR data. The NIWA FTIR program is funded through the New Zealand government's core research grant framework from the Ministry of Business, Innovation and Employment.

Edited by: William Lahoz

Reviewed by: Eric Ray and one anonymous referee

\section{References}

Abalos, M., Legras, B., Ploeger, F., and Randel, W. J.: Evaluating the advective Brewer-Dobson circulation in three reanalyses for the period 1979-2012, J. Geophys. Res.-Atmos., 120, 75347554, https://doi.org/10.1002/2015JD023182, 2015.

Austin, J. and Li, F.: On the relationship between the strength of the Brewer-Dobson circulation and the age of stratospheric air, Geophys. Res. Lett., 33, L17807, https://doi.org/10.1029/2006GL026867, 2006.

Bernath P. F., McElroy, C. T., Abrams, M. C., Boone, C. D., Butler, M., Camy-Peyret, C., Carleer, M., Clerbaux, C., Coheur, P.-F., Colin, R., DeCola, P., DeMazière, M., Drummond, J. R., Dufour, D., Evans, W. F. J., Fast, H., Fussen, D., Gilbert, K., Jennings, D. E., Llewellyn, E. J., Lowe, R. P., Mahieu, E., McConnell, J. C., McHugh, M., McLeod, S. D., Michaud, R., Midwinter, C., Nassar, R., Nichitiu, F., Nowlan, C., Rinsland, C. P., Rochon, Y. J., Rowlands, N., Semeniuk, K., Simon, P., Skelton, R., Sloan, J. J., Soucy, M.-A., Strong, K., Tremblay, P., Turnbull, D., Walker, K. A., Walkty, I., Wardle, D. A., Wehrle, V., Zander, R., and Zou, J.: Atmospheric Chemistry Experiment (ACE): Mission overview, Geophys. Res. Lett., 32, L15S01, https://doi.org/10.1029/2005GL022386, 2005.

Burkholder, J. B., Sander, S, P., Abbatt, J., Barker, J. R., Huie, R. E., Kolb, C. E., Kurylo, M. J., Orkin, V. L., Wilmouth, D. M., and Wine, P. H.: Chemical Kinetics and Photochemical Data for Use in Atmospheric Studies, Evaluation No. 18, JPL Publication 1510, Jet Propulsion Laboratory, Pasadena, http://jpldataeval.jpl. nasa.gov (last access: 3 October 2017), 2015.

Butchart, N. and Scaife, A. A.: Removal of chlorofluorocarbons by increased mass exchange between the stratosphere and troposphere in a changing climate, Nature, 410, 799-802, https://doi.org/10.1038/35071047, 2001.

Butchart, N., Butchart N., Scaife, A. A., Bourqui, M., de Grandpré, J., Hare, S. H. E., Kettleborough, J., Langematz, U., Manzini, E., Sassi, F., Shibata, K., Shindell, D., and Sigmond, M.: Simulations of anthropogenic change in the strength of the Brewer-Dobson circulation, Clim. Dynam., 27, 727-741, https://doi.org/10.1007/s00382-006-0162-4, 2006.

Carpenter, L. J., Reimann, S., Burkholder, J. B., Clerbaux, C., Hall, B. D., Hossaini, R., Laube, J. C., and Yvon-Levis, S. A.: OzoneDepleting Substances (ODSs) and Other Gases of Interest to the Montreal Protocol, in: chap. 1 in Scientific Assessment of Ozone Depletion: 2014, Global Ozone Research and Monitoring Project - Report No. 55, World Meterological Organization, Geneva, Switzerland, 2014.

Coy, L., Wargan, K., Molod, A., McCarty, W. R., and Pawson, S.: Structure and dynamics of the Quasi-Biennial Oscillation, J. Climate, 29, 5339-5354, https://doi.org/10.1175/JCLI-D-150809.1, 2016.

Diallo, M., Legras, B., and Chédin, A.: Age of stratospheric air in the ERA-Interim, Atmos. Chem. Phys., 12, 12133-12154, https://doi.org/10.5194/acp-12-12133-2012, 2012.

Douglass, A. R., Stolarski, R. S., Schoeberl, M. R., Jackman, C. H., Gupta, M. L., Newman, P. A., Nielsen, J. E., and Fleming, E. L.: Relationship of loss, mean age of air and the distribution of CFCs to stratospheric circulation and implications for atmospheric lifetimes, J. Geophys. Res., 113, D14309, https://doi.org/10.1029/2007JD009575, 2008.

Douglass, A. R., Strahan, S. E., Oman, L. D., and Stolarski, R. S.: Understanding differences in chemistry climate model projections of stratospheric ozone, J. Geophys. Res.-Atmos., 119, 4922-4939, https://doi.org/10.1002/2013JD021159, 2014.

Duncan, B. N., Strahan, S. E., Yoshida, Y., Steenrod, S. D., and Livesey, N.: Model study of the cross-tropopause transport of biomass burning pollution, Atmos. Chem. Phys., 7, 3713-3736, https://doi.org/10.5194/acp-7-3713-2007, 2007.

Engel, A., Möbius, T., Bönisch, H., Schmidt, U., Heinz, R., Levin, I., Atlas, E., Aoki, S., Nakazawa, T., Sugawara, S., Moore, F., Hurst, D., Elkins, J., Schauffler, S., Andrews, A., and Boering, K.: Age of stratospheric air unchanged within uncertainties over the past 30 years, Nat. Geosci., 2, 28-31, https://doi.org/10.1038/NGEO388, 2009.

Frith, S. M., Kramarova, N. A., Stolarski, R. S., McPeters, R. D., Bhartia, P. K., and Labow, G. J.: Recent changes in total column ozone based on the SBUV Version 8.6 Merged Ozone Data Set, J. Geophys. Res.-Atmos., 119, 9735-9751, https://doi.org/10.1002/2014JD021889, 2014.

Garcia, R. R., Randel, W. J., and Kinnison, D. E.: On the determination of age of air trends from atmospheric trace species, J. Atmos. Sci., 68, 139-154, https://doi.org/10.1175/2010JAS3527.1, 2011.

Gebhardt, C., Rozanov, A., Hommel, R., Weber, M., Bovensmann, H., Burrows, J. P., Degenstein, D., Froidevaux, L., and Thompson, A. M.: Stratospheric ozone trends and variability as seen by SCIAMACHY from 2002 to 2012, Atmos. Chem. Phys., 14, 831-846, https://doi.org/10.5194/acp-14-831-2014, 2014.

Gelaro, R., McCarty, W., Suarez, M. J., Todling, R., Molod, A., Takacs, L., Randles, C. A., Darmenov, A., Bosilovich, M. G., Reichle, R., Wargan, K., Coy, L., Cullather, R., Draper, C., Akella, S., Buchard, V., Conaty, A., da Silva, A. M., Gu, W., Kim, G. K., Koster, R., Lucchesi, R., Merkova, D., Nielsen, J. E., Partyka, G., Pawson, S., Putman, W., Rienecker, M., Schubert, S. D., Sienkiewicz, M., and Zhao, B.: The Modern-Era Retrospective Analysis for Research and Applications, Version 2 (MERRA-2), 
J. Climate, 30, 5419-5454, https://doi.org/10.1175/JCLI-D-16$0758.1,2017$.

Grooß, J.-U. and Russell III, J. M.: Technical note: A stratospheric climatology for $\mathrm{O}_{3}, \mathrm{H}_{2} \mathrm{O}, \mathrm{CH}_{4}, \mathrm{NO}_{x}, \mathrm{HCl}$ and $\mathrm{HF}$ derived from HALOE measurements, Atmos. Chem. Phys., 5, 2797-2807, https://doi.org/10.5194/acp-5-2797-2005, 2005.

Hall, T. M.: Path histories and timescales in stratospheric transport: Analysis of an idealized model, J. Geophys. Res., 105, 2281122823, https://doi.org/10.1029/2000JD900329, 2000.

Hall, T. M., Waugh, D. W., Boering, K. A., and Plumb, R. A.: Evaluation of transport in stratospheric models, J. Geophys. Res., 104, 18815-18839, https://doi.org/10.1029/1999JD900226, 1999.

Harris, N. R. P., Hassler, B., Tummon, F., Bodeker, G. E., Hubert, D., Petropavlovskikh, I., Steinbrecht, W., Anderson, J., Bhartia, P. K., Boone, C. D., Bourassa, A., Davis, S. M., Degenstein, D., Delcloo, A., Frith, S. M., Froidevaux, L., GodinBeekmann, S., Jones, N., Kurylo, M. J., Kyrölä, E., Laine, M., Leblanc, S. T., Lambert, J.-C., Liley, B., Mahieu, E., Maycock, A., de Mazire, M., Parrish, A., Querel, R., Rosenlof, K. H., Roth, C., Sioris, C., Staehelin, J., Stolarski, R. S., Stübi, R., Tamminen, J., Vigouroux, C., Walker, K. A., Wang, H. J., Wild, J., and Zawodny, J. M.: Past changes in the vertical distribution of ozone - Part 3: Analysis and interpretation of trends, Atmos. Chem. Phys., 15, 9965-9982, https://doi.org/10.5194/acp15-9965-2015, 2015.

Hegglin, M. I. and Shepherd, T. G.: Large climate-induced changes in ultraviolet index and stratosphere-to-troposphere ozone flux, Nat. Geosci., 2, 687-691, 2009.

Kawatani, Y. and Hamilton, K.: Weakened stratospheric quasibiennial oscillation driven by increased tropical mean upwelling, Nature, 497, 478-481, https://doi.org/10.1038/nature12140, 2013.

Lambert, A., Livesey, N., and Read, W.: MLS/Aura Level 2 Nitrous Oxide $\left(\mathrm{N}_{2} \mathrm{O}\right)$ Mixing Ratio V004, Greenbelt, MD, USA, Goddard Earth Sciences Data and Information Services Center (GES DISC), https://doi.org/10.5067/AURA/MLS/DATA2016, 2015.

Li, F., Stolarski, R. S., and Newman, P. A.: Stratospheric ozone in the post-CFC era, Atmos. Chem. Phys., 9, 2207-2213, https://doi.org/10.5194/acp-9-2207-2009, 2009.

Li, S. and Waugh, D. W.: Sensitivity of mean age and long-lived tracers to transport parameters in a twodimensional model, J. Geophys. Res., 104, 30559-30569, https://doi.org/10.1029/1999JD900913, 1999.

Livesey, N., Read, W. G., Wagner, P. A., Froidevaux, L., Lambert, A., Manney, G. L., Millán Valle, L. F., Pumphrey, H. C., Santee, M. L., Schwartz, M. J., Wang, S., Fuller, R. A., Jarnot, R. F., Knosp, B. W., and Martinez, E.: Earth Observing System (EOS) Aura Microwave Limb Sounder (MLS) version 4.2x level 2 data quality and description document, JPL D-33509 Rev C, JPL, Pasadena, CA, 2017.

Mahieu, E., Chipperfield, M. P., Nothold, J., Reddmann, T., Anderson, J., Bernath, P. F., Blumenstock, T., Coffey, M. T., Dhomse, S. S., Feng, W., Franco, B., Froidevaux, L., Griffith, D. W. T., Hannigan, J. W., Hase, F., Hossaini, R., Jones, N. B., Morino, I., Murata, I., Nakajima, H., Palm, M., Paton-Walsh, C., Russell, J. M., Schneider, M., Servais, C., Smale, D., and Walker, K. A.: Recent northern hemisphere stratospheric $\mathrm{HCl}$ increase due to atmospheric circulation changes, Nature, 515, 104-107, https://doi.org/10.1038/nature13857, 2014.
McPeters, R. D., Bhartia, P. K., Haffner, D., Labow, G. J., and Flynn, L.: The version 8.6 SBUV ozone data record: An overview, J. Geophys. Res.-Atmos., 118, 8032-8039, https://doi.org/10.1002/jgrd.50597, 2013.

Molod, A., Takacs, L. L., Suarez, M. J., Bacmeister, J. T., Song, I.-S., and Eichmann, A.: The GEOS-5 Atmospheric General Circulation Model: Mean Climate and Development from MERRA to Fortuna, in: Series on Global Modeling and Data Assimilation, NASA Tech. Memo. 104606, Vol. 28, Tech. Rep., edited by: Suarez, M. J., NASA, Greenbelt, MD, 117 pp., 2012.

Molod, A., Takacs, L., Suarez, M., and Bacmeister, J.: Development of the GEOS-5 atmospheric general circulation model: evolution from MERRA to MERRA2, Geosci. Model Dev., 8, 1339-1356, https://doi.org/10.5194/gmd-8-1339-2015, 2015.

Oman, L. D., Douglass, A. R., Ziemke, J. R., Rodriguez, J. M., Waugh, D. W., and Nielsen, J. E.: The ozone response to ENSO in Aura satellite measurements and a chemistry-climate simulation, J. Geophys. Res., 118, 965-976, https://doi.org/10.1029/2012JD018546, 2013.

Park, J., Ko, M. K. W., Plumb, R. A., Jackman, C. H., Kaye, J. A., and Sage, K. H.: Report of the 1998 Models and Measurements II Workshop, NASA Tech. Publ., NASA/TM-1999209554, NASA, 1999.

Pawson, S., and Steinbrecht, W. (Lead Authors), Charlton-Perez, A. J., Fujiwara, M., Karpechko, A. Yu, Petropavlovskikh, I., Urban, J., and Weber, M.: Update on global ozone: Past, present, and future, in: chap. 2 in Scientific Assessment of Ozone Depletion: 2014, Global Ozone Research and Monitoring Project - Report No. 55, World Meteorological Organization, Geneva, Switzerland, 2015.

Ploeger, F., Abalos, M., Birner, T., Konopka, P., Legras, B., Müller, R., and Riese, M.: Quantifying the effects of mixing and residual circulation on trends of stratospheric mean age of air, Geophys. Res. Lett., 42, 2047-2054, https://doi.org/10.1002/2014GL062927, 2015.

Polvani, L. M., Want, L., Aquila, V., and Waugh, D. D.: The Impact of Ozone-Depleting Substances on Tropical Upwelling, as Revealed by the Absence of Lower Stratospheric Cooling since the Late 1990s, J. Climate, 30, 2523-2534, https://doi.org/10.1175/JCLI-D-16-0532.1, 2017.

Ramanathan, V.: Greenhouse effect due to chlorofluorocarbons: climatic implications, Science, 190, 50-52, https://doi.org/10.1126/science.190.4209.50, 1975.

Randel, W. J. and Thompson, A. M.: Interannual variability and trends in tropical ozone derived from SAGE II satellite data and SHADOZ ozonesondes, J. Geophys. Res., 116, D07303, https://doi.org/10.1029/2010JD015195, 2011.

Randel, W. J. and Wu, F.: A stratospheric ozone profile data set for 1979-2005: Variability, trends, and comparisons with column ozone data, J. Geophys. Res., 112, D06313, https://doi.org/10.1029/2006JD007339, 2007.

Ray, E. A., Moore, F. L., Rosenlof, K. H., Davis, S. M., Bönisch, H., Morgenstern, O., Smale, D., Rozanov, E., Hegglin, M., Pitari, G., Mancini, E., Braesicke, P., Butchart, N., Hardiman, S., Li, F., Shibata, K., and Plummer, D. A.: Evidence for changes in stratospheric transport and mixing over the past three decades based on multiple data sets and tropical leaky pipe analysis, J. Geophys. Res., 115, D21304, https://doi.org/10.1029/2010JD014206, 2010. 
Ray, E. A., Moore, F. L., Rosenlof, K. H., Davis, S. M., Sweeney, C., Tans, P., Wang, T., Elkins, J. W., Bönisch, H., Engel, A., Sugawara, S., Nakazawa, T., and Aoki, S..: Improving stratospheric transport trend analysis based on $\mathrm{SF}_{6}$ and $\mathrm{CO}_{2}$ measurements, J. Geophys. Res.-Atmos., 119, 14110-14128, https://doi.org/10.1002/2014JD021802, 2014.

Rayner, N. A., Parker, D. E., Horton, E. B., Folland, C. K., Alexander, L. V., Rowell, D. P., Kent, E. C., and Kaplan, A.: Global analyses of sea surface temperature, sea ice, and night marine air temperature since the late nineteenth century, J. Geophys. Res., 108, 4407, https://doi.org/10.1029/2002JD002670, 2003.

Rienecker, M. M., Suarez, M. J., Roding, R., Bacmeister, J., Takacs, L., Liu, H.-C., Gu, W., Sienkiewicz, M., Koster, R. D., Gelaro, R., Stajner, I., and Nielsen, J. E.: The GEOS-5 data assimilation system - Documentation of versions 5.0.1, 5.1.0, and 5.2.0, Technical Report Series on Global Modeling and Data Assimilation, available at: https://gmao.gsfc.nasa.gov/ (last access: 3 October 2017), 2008.

Rienecker, M. M, Suarez, M. J., Gelaro, R., Todling, R., Bacmeister, J., Liu, E., Bosilovich, M. G., Schubert, S. D., Takacs, L., Kim, G. K., Bloom, S., Chen, J. Y., Collins, D., Conaty, A., Da Silva, A., Gu, W., Joiner, J., Koster, R. D., Lucchesi, R., Molod, A., Owens, T., Pawson, S., Pegion, P., Redder, C. R., Reichle, R., Robertson, F. R., Ruddick, A. G., Sienkiewicz, M., and Woollen, J.: MERRA: NASA's Modern Era Retrospective Analysis for Research and Applications, J. Climate, 24, 3624-3648, 2011.

Roche, A. E., Kumer, J. B., Nightingale, R. W., Mergenthaler, J. L., Ely, G. A., Bailey, P. L., Massie, S. T., Gille, J. C., Edwards, D P., Gunson, M. R., Abams, M. C., Toon, G. C., Webster, C. R., Traub, W. A., Jucks, K. W., Johnson, D. G., Murcray, D. G., Murcray, F. H., Goldman, A., and Zipf, E. C.: Validation of $\mathrm{CH}_{4}$ and $\mathrm{N}_{2} \mathrm{O}$ measurements by the cryogenic limb array etalon spectrometer instrument on the upper atmosphere research satellite, J. Geophys. Res., 101, 9679-9710, https://doi.org/10.1029/95JD03442, 1996.

Ronsmans, G., Langerock, B., Wespes, C., Hannigan, J. W., Hase, R., Kerzenmacher, T., Mahieu, E., Schneider, M., Smale, D., Hurtmans, D., De Maziere, M., Clerbaux, C., and Coheur, P. F.: First characterization and validation of FORLI-HNO 3 vertical profiles retrieved from IASI/Metop, Atmos. Meas. Tech., 9, 4783-4801, https://doi.org/10.5194/amt-9-4783-2016, 2016.

Russell III, J. M.: UARS Halogen Occultation Experiment (HALOE) Level 2 V019, Greenbelt, MD, USA, Goddard Earth Sciences Data and Information Services Center (GES DISC), https://disc.gsfc.nasa.gov/datacollection/UARHA2FN_ 019.html (last access: 3 October 2017), 1999.

Russell III, J. M., Gordley, L. L., Park, J. H., Drayson, S. R., Hesketh, W. D., Cicerone, R. J., Tuck, A. F., Frederick, J. E., Harries, J. E., and Crutzen, P. J.: The Halogen Occultation Experiment, J. Geophys. Res., 98, 10777-10797, https://doi.org/10.1029/93JD00799, 1993.

Schauffler, S. M., Atlas, E. L., Donnelly, S. G., Andrews, A., Montzka, S. A., Elkins, J. W., Hurst, D. F., Romashkin, P. A., Dutton, G. S., and Stroud, V.: Chlorine budget and partitioning during the Stratospheric Aerosol and Gas Experiment (SAGE) III Ozone Loss and Validation Experiment (SOLVE), J. Geophys. Res., 108, 4173, https://doi.org/10.1029/2001JD002040, 2003.

Schoeberl, M. R., Sparling, L. C., Jackman, C. H., and Fleming, E. L.: A Lagrangian view of stratospheric trace gas distributions, J. Geophys. Res., 105, 1537-1552, https://doi.org/10.1029/1999JD900787, 2000.

Schoeberl, M. R., Douglass, A. R., Polansky, B., Boone, C., Walker, K. A., and Bernath, P.: Estimation of stratospheric age spectrum from chemical tracers, J. Geophys. Res., 110, D21303, https://doi.org/10.1029/2005JD006125, 2005.

Shepherd, T. G., Plummer, D. A., Scinocca, J .F., Hegglin, M. I., Fioletov, V. E., Reader, M. C., Remsberg, E., von Clarmann, T., and Wang, H. J.: Reconciliation of halogen-induced ozone loss with the total-column ozone record, Nat. Geosci., 7, 443-449, https://doi.org/10.1038/ngeo2155, 2014.

SPARC CCMVal: SPARC report on the Evaluation of ChemistryClimate Models, edited by: Eyring, V., Shepherd, T. G., and Waugh, D. W., SPARC Report No. 5, WCRP-132, WMO/TDNo. 1526, WMO, 2010.

Strahan, S. E., Duncan, B. N., and Hoor, P.: Observationally derived transport diagnostics for the lowermost stratosphere and their application to the GMI chemistry and transport model, Atmos. Chem. Phys., 7, 2435-2445, https://doi.org/10.5194/acp-72435-2007, 2007.

Strahan, S. E., Douglass, A. R., Stolarski, R. S., Akiyoshi, H., Bekki, S., Braesicke, P., Butchart, N., Chipperfield, M. P., Cugnet, D., Dhomse, S., Frith, S. M., gettelman, A., Hardiman, S. C., Kinnison, D. E., Lamarque, J.-F., Mancini, E., Marchand, M., Michou, M., Morgenstern, O., Nakamura, T., Olivié, D., Pawson, S., Pitari, G., Plummer, d. A., Pyle, J. A., Scinocca, J. F., Shepherd, T. G., Shibata, K., Smale, D., Teyssèdre, Tian, W., and Yamashita, Y.: Using transport diagnostics to understand chemistry climate model ozone simulations, J. Geophys. Res., 116, D17302, https://doi.org/10.1029/2010JD015360, 2011.

Strahan, S. E., Douglass, A. R., and Newman, P. A.: The contributions of chemistry and transport to low Arctic ozone in March 2011 derived from Aura MLS Observations, J. Geophys. Res., 118, 1563-1576, https://doi.org/10.1002/jgrd.50181, 2013.

Strahan, S. E., Oman, L. D., Douglass, A. R., and Coy, L.: Modulation of Antarctic vortex composition by the QuasiBiennial Oscillation, Geophys. Res. Lett., 42, 4216-4223, https://doi.org/10.1002/2015GL063759, 2015.

Strahan, S. E., Douglass, A. R., and Steenrod, S. D.: Chemical and Dynamical Impacts of Stratospheric Sudden Warmings on Arctic Ozone Variability, J. Geophys. Res., 121, 11836-11851, https://doi.org/10.1002/2016JD025128, 2016.

Tan, W. W., Geller, M. A., Pawson, S., and da Silva, A.: A case study of excessive subtropical transport in the stratosphere of a data assimilation system, J. Geophys. Res., 109, D11102, https://doi.org/10.1029/2003JD004057, 2004.

Thompson, D. W. J. and Solomon, S.: Understanding Recent Stratospheric Climate Change, J. Climate, 22, 1934-1943, https://doi.org/10.1175/2008JCLI2482.1, 2009.

Waugh, D. W. and Hall, T. M.: Age of stratospheric air: Theory, observations and models, Rev. Geophys., 40, 1-1-1-26, https://doi.org/10.1029/2000RG000101, 2002.

Waugh, D. W., Strahan, S. E., and Newman, P. A.: Sensitivity of stratospheric inorganic chlorine to differences in transport, Atmos. Chem. Phys., 7, 4935-4941, https://doi.org/10.5194/acp-74935-2007, 2007.

WMO - World Meteorological Organization: Scientific Assessment of Ozone Depletion: 2010, Global Ozone Research and Monitoring Project - Report No. 52, Geneva, Switzerland, 516 pp., 2011. 